Energy Systems Environmental Restoration Program

ORNL Environmental Restoration Program

\title{
Design/Installation and Structural Integrity Assessment of Bethel Valley Low-Level Waste Collection and Transfer System Upgrade for Building 2649 (Transported Waste Receiving Facility) at Oak Ridge National Laboratory
}

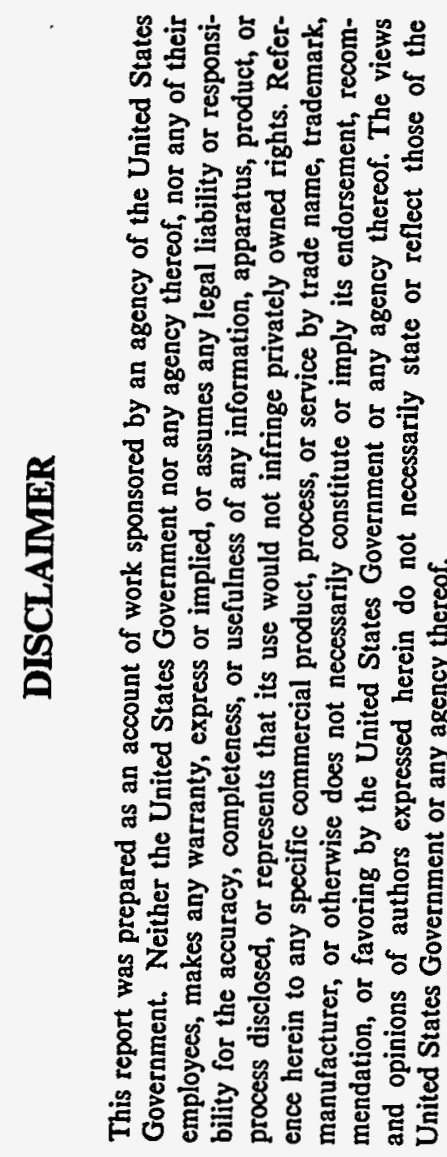

Date Issued-January 1995

\author{
Prepared by \\ Gilbert/Commonwealth, Inc. \\ Oak Ridge, Tennessee \\ under subcontract 32X-GJF75C \\ Prepared for
}

U.S. Department of Energy

Office of Environmental Restoration and Waste Management under budget and reporting code EW 20

Environmental Restoration and Waste Management Programs Oak Ridge National Laboratory

Oak Ridge, Tennessee 37831-6285 managed by MARTIN MARIETTA ENERGY SYSTEMS, INC. for the U.S. DEPARTMENT OF ENERGY under contract DE-AC05-84OR21400

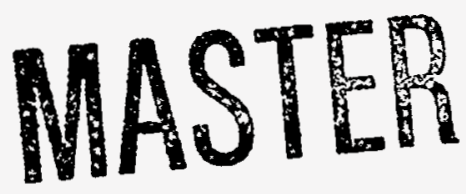

DISTRIBUTION OF THIS DOCUAENT IS UNLMTED 


\section{DISCLAIMER}

Portions of this document may be illegible in electronic image products. Images are produced from the best available original document. 
I. Introduction

II. Description of Project 2

III. Purpose of Project 4

$\begin{array}{ll}\text { IV. Assessment Results } & 7\end{array}$

A. Introduction 7

B. Standards for Design/Installation of New or Replacement Tank Systems

1. Design Installation Assessment 12

(a) Design Standards 12

(b) Hazardous Substance Characteristics 28

(c) Corrosion Protection 33

(d) Vehicular Traffic Protection 35

(e) Design Considerations 37

2. Tank Systems Installation 39

3. Inspection Reports 46

4. Backfilling 49

5. Testing 51

6. Ancillary Equipment Protection 51

7. Corrosion Protection 53

8. Corrosion Expert 53

9. Documentation 54 


\section{TABLE OF CONTENTS}

Page

C. Standards for Containment/Release Detection 57

1. Secondary Containment Systems Requirements 57

(a) Construction Compatibility 57

(b) Containment Systems Foundation 59

(c) Leak Detection System 61

(d) Drainage and Liquid Removal 62

(e) Secondary Containment for Tanks 64

(f) Additional Requirements 64

$\begin{array}{ll}\text { V. Conclusions } & 75\end{array}$

Appendix A: Drawing List of Transported Waste Receiving Facility-Building $2649 \quad 77$ 


\section{INTRODUCTION}

This document presents a Design/Installation and Structural Integrity Assessment for a new tank system for portions of the Bethel Valley Low Level Waste (LLW) System, located at the Oak Ridge Reservation, Oak Ridge, Tennessee. This issue of the assessment covers the design aspects of the new tank system, and certifies that the design has sufficient structural integrity and is acceptable for the storing or treating of hazardous and/or radioactive substances.

This document will be reissued at a future date and will then include the assessment of the installation of the new tank system. The present issue identifies specific activities that must be completed during the fabrication, installation, and testing of the new tank system in order to provide assurance that the final installation complies with governing requirements. These requirements are based on meeting the intent of 40CFR264 Subpart J - Tank Systems, as set forth in Appendix F to the Federal Facility Agreement, Docket No. 89-04-FF, covering the Oak Ridge Reservation.

The assessment presented in this document is responsive to the Environmental Restoration Agreement for the Oak Ridge Reservation. The format utilized in preparation of the document follows the format presented in Appendix F, Low Level Radioactive Waste Tank Systems, appended to the Agreement. 


\section{DESCRIPTION OF PROJECT}

The LLW system at Oak Ridge National Laboratory (ORNL) consists of facilities to collect, transfer, concentrate, and store aqueous radioactive waste solutions from various sources at the Laboratory. The system is designed to accommodate waste solutions having an activity content as high as $5 \mathrm{Ci} / g a l$. The collection and transfer system consists of an extensive network of underground piping, valve boxes, and collection tanks. It allows for collection of LLW from the various source facilities and periodic transfer through the Central Waste Collection Header ( $\mathrm{CWCH}$ ) to the storage tanks serving the Laboratory's central LLW evaporator. Status of various system operations is centrally monitored at the Laboratory's Waste Operations Control Center (WOCC). Wastes are concentrated at the evaporator, and the concentrate is collected in a local storage tank and periodically transferred to tanks located in the Melton Valley area of the Laboratory for storage.

The Exhibit II-1 presents a map of a portion of the Bethel Valley complex, showing all of the facilities, existing and new, that compose the entire scope of the Bethel Valley LLW Upgrade Project. This assessment report pertains to a new facility, Building 2649, known as the Transported Waste Receiving Facility (TWRF). The TWRF arrangement and function are described in Sections III and IV. Other aspects of the Bethel Valley LLW Upgrade are assessed in separate reports.

The limits of the probable maximum flood, due to extreme flood stage for White Oak Creek, are superimposed on Exhibit II-1. As may be noted, site flooding from this type of phenomena is not a credible event for the Transported Waste Receiving Facility, (Building 2649) portion of the upgrade. 


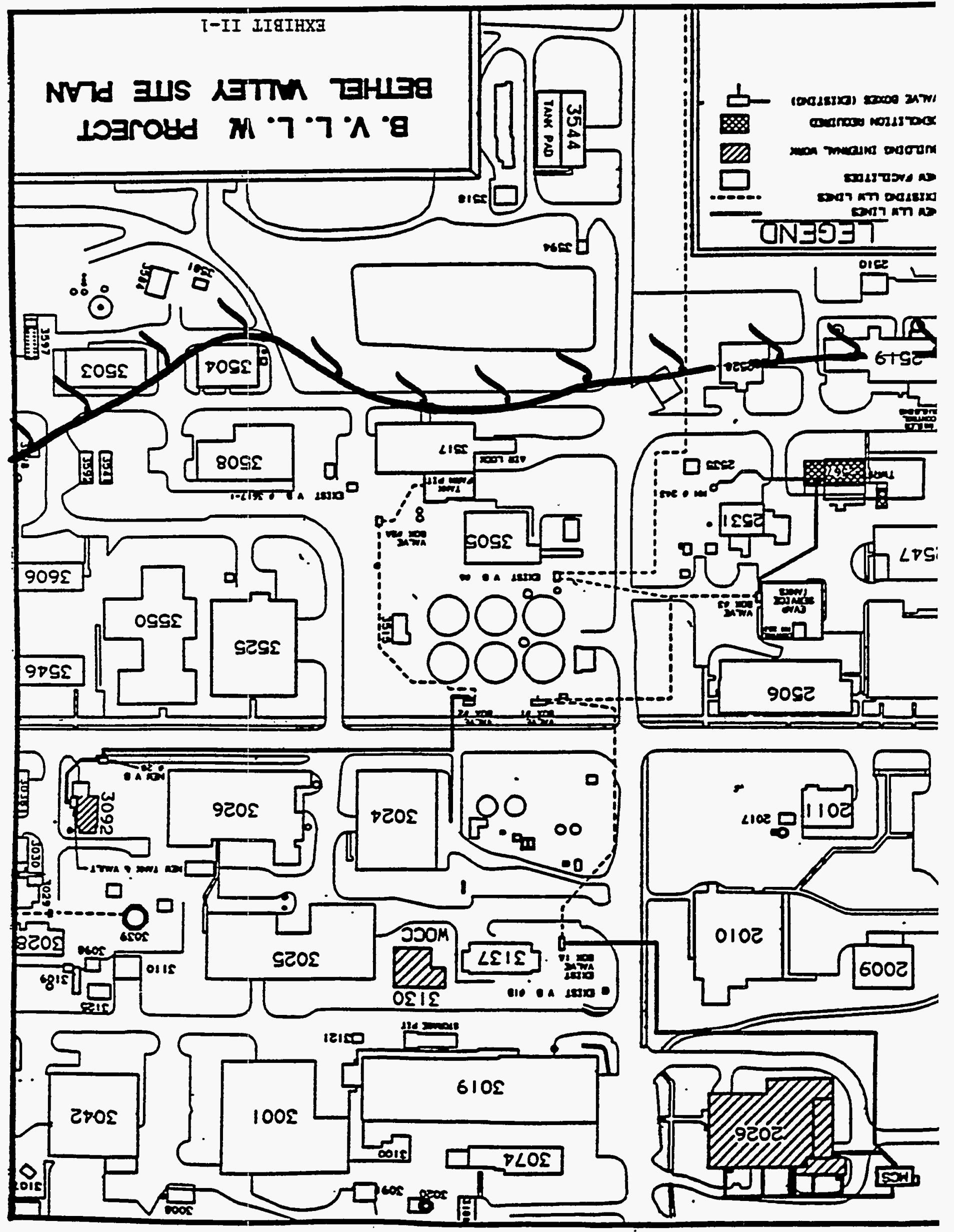




\section{PURPOSE OF PROJECT}

Portions of the LLW system are several decades old, or older, and do not comply with current environmental protection regulations. Several subsystems of the LLW system have been designated to receive an upgrade, in the form of a state-of-the-art replacement and refurbishment. In the case of certain ORNL waste generating facilities, the upgrade consists of new permanent double wall piping systems to convey waste underground to a monitoring and collection station. However, other facilities do not generate waste in sufficient quantities to justify the addition of a new piping subsystem. For these facilities a different upgrade approach is taken as explained below.

This assessment focuses on the capability of the new tank system associated with Building 2649, known as the Transported Waste Receiving Facility (TWRF), to receive, neutralize $(\mathrm{pH})$ and provide for sampling of hazardous and/or radioactive liquid waste. At periodic intervals, the waste is transferred via a new buried pipeline to existing valve box No. 3, which has been modified to accept tie-in of the new piping to the $\mathrm{CWCH}$.

The TWRF is a new facility designed to receive level waste transported on either of two types of trucks. One type of truck transports contact-handleable waste in three gallon containers (also termed "bottles"), collected from ORNL facilities that generate small quantities of such waste on a regular basis. The second is a tanker type truck capable of transporting larger quantities of LLW from facilities that may require removal of this type and quantity of waste on a special use basis.

The TWRF comprises several physically and functionally distinctive areas arranged to serve the overall facility requirements. These areas include a one story main building located at grade, a below grade tank vault complex, an HVAC equipment area located at grade, an auxiliary building housing sampling equipment, and buried double wall transfer piping.

The TWRF main building contains a truck parking area for both types of trucks described above; an air conditioned control room and rest rooms; a truck unloading zone designed to receive and unload both types of truck described above; and a bottle unloading zone with facilities to decant and . 
decontaminate the three gallon transport containers. The TWRF sample building houses equipment for removing samples from the two waste tanks. The HVAC equipment area, located at grade, contains fans, filters, and a discharge stack.

The tank vault complex contains two waste tanks in stainless steel lined concrete vaults, with leak detection and liquid removal provisions, filtered ventilation systems, and caustic addition capability for $\mathrm{pH}$ adjustment of the tank contents. The tank vault complex is similar in design to a typical Monitoring and Control Station, and may be referred to as the MCS portion of the TWRF.

One of the two waste tanks (the LLW tank), receives the liquid waste transported to the TWRF by the special trucks, including waste removed from the 3-gallon containers. The second tank, (PW tank), receives process waste (PW) from floor drains in the bottle unloading zone and change room, drains from the shower in the change room, and floor drains from the truck unloading zone. The PW tank is designed to the same criteria as is the LLW tank and serves as a backup to the LLW tank if needed.

The LLW and PW piping from the truck unloading and bottle unloading zones is routed to the LLW and PW tank vaults via a covered, shielded trench below the floor of the aforementioned zones. The trench is lined with stainless steel, providing a secondary containment boundary for the primary fluid piping contained within the trench. The trench floor slopes to a low point at one end, which is provided with a level detection instrument. This assessment has determined that a means of access to the low point of the trench is required to enable a sample to be taken, and to permit removal of accumulated liquid in the event of a leak from one of the pipes in the trench. This feature will be added in a design change.

For the purpose of this assessment, the following terms are defined:

- Tank is defined as the LLW or Process Waste (PW) tank provided in the MCS portion of the TWRF; this term is limited to one or the other tank proper and excludes the tank vaults, liners, and other design features. 
- Tank System is defined as the entire fluid retaining system for waste from the collection points within the TWRF building to the LLW and PW tanks, and then to valve box No. 3. This includes the LLW and PW tanks, the lined vaults (with stainless steel inner liners), the sump in each vault with level detection instrumentation, the accumulated liquid removal subsystem (steam jet ejectors and associated piping), and piping connecting the TWRF with valve box No. 3 .

- Primary Fluid Boundary is defined as piping containing LLW, including single wall piping within the building, the inner pipe in double wall pipe runs, and the LLW and PW tanks.

- Secondary Containment is defined as the outer pipe in double wall pipe runs, and the reinforced concrete vaults, with inner stainless steel liners, at the MCS portion of the TWRF. These vaults include the LLW and PW tank and mist eliminator vaults, and a common valve vault for the piping and valves associated with the LLW and PW tanks. The lined, covered trench from the Truck Unloading Zone to the valve vault constitutes the secondary containment for the piping in the trench.

- Support Equipment is defined as, but not necessarily limited to, equipment required for system functional capability, such as sump level instrumentation, steam jet ejectors and associated piping and valves, and ventilating equipment for the tanks and vaults. 


\section{ASSESSMENT RESULTS}

\section{A. Introduction}

This assessment covers the LLW Collection and Transfer System designed for installation to serve Building 2649, Transported Waste Receiving Facility; and piping systems connecting Building 2649 with the ORNL Central Waste Collection Header, ( $\mathrm{CWCH}$ ). The transfer line from Building 2649 terminates at, and connects to, the $\mathrm{CWCH}$ at existing valve box No. 3 .

This assessment reviews the design of the new Tank System for the above described Building 2649 (Section IV.B). The assessment also covers the secondary containment provisions and ancillary equipment associated with Building 2649 (Section IV.C). Simplified diagrams illustrating the schematic and physical aspects of this LLW subsystem are shown in Exhibits IV-1, IV-2, and IV-3.

Several design conditions are presented for evaluation, as follows:

- Single wall pipe routed within a building, where the pipe is visible for routine (i.e., daily) visual inspection to detect leakage. Potential leakage is limited to small amounts of fluid that would be detected by routine observations and could not be directly released to the environment since it would spill or drip on floors, walls, or interior building furnishings. This condition is manifested in limited portions of the new Building 2649 internal piping, which consists of small diameter drain lines serving the Bottle Evacuation and Decontamination Assemblies (BEDA's), and the truck unloading connection in the Truck Unloading Zone.

- Single wall pipe routed within a vaulted structure, where the piping is not visible for routine visual inspection. Potential leakage would be contained and detected by the retention and leak detection capabilities of the stainless steel lined vaults and trench as described in Section IV.C of this assessment. 


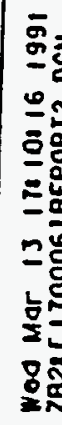

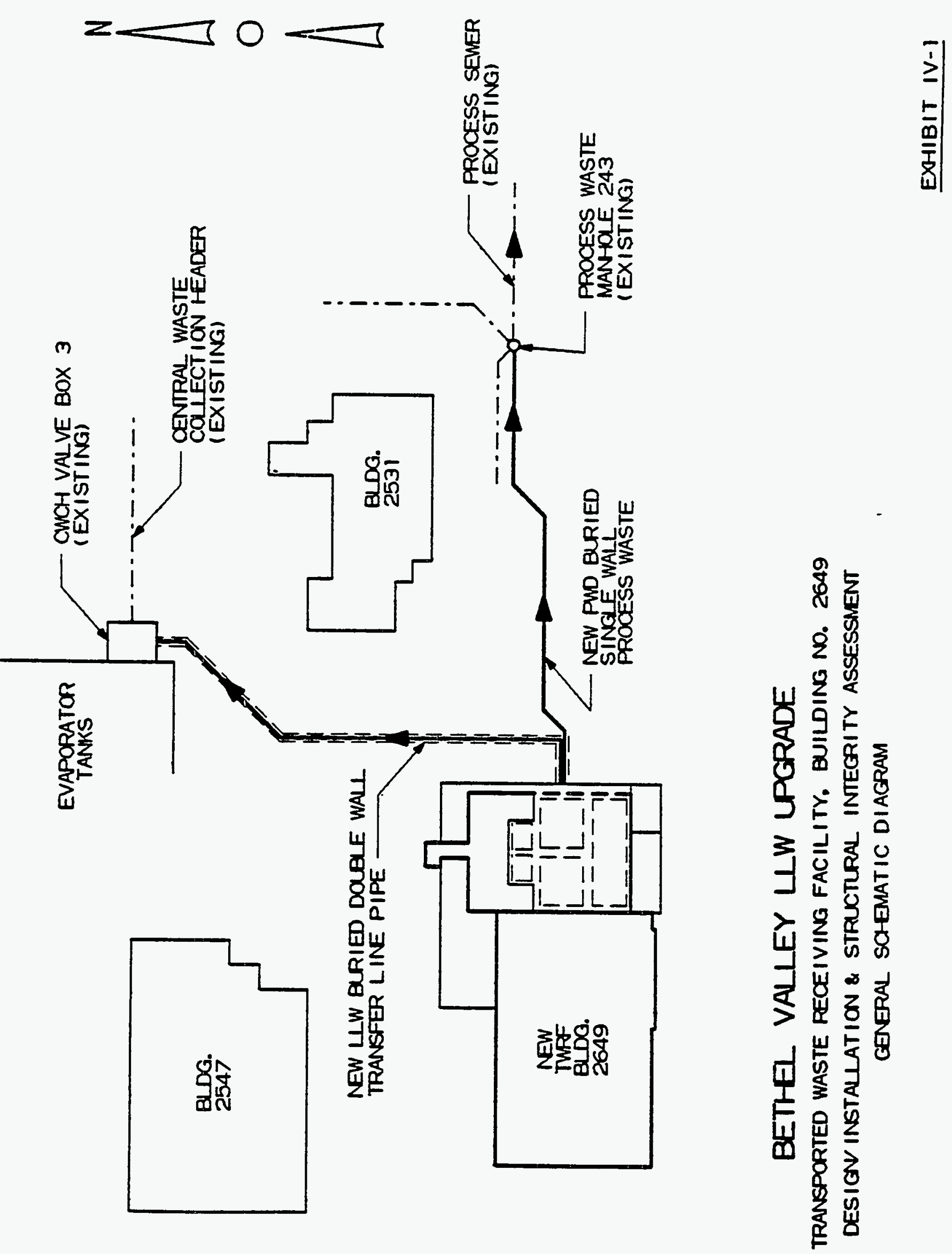




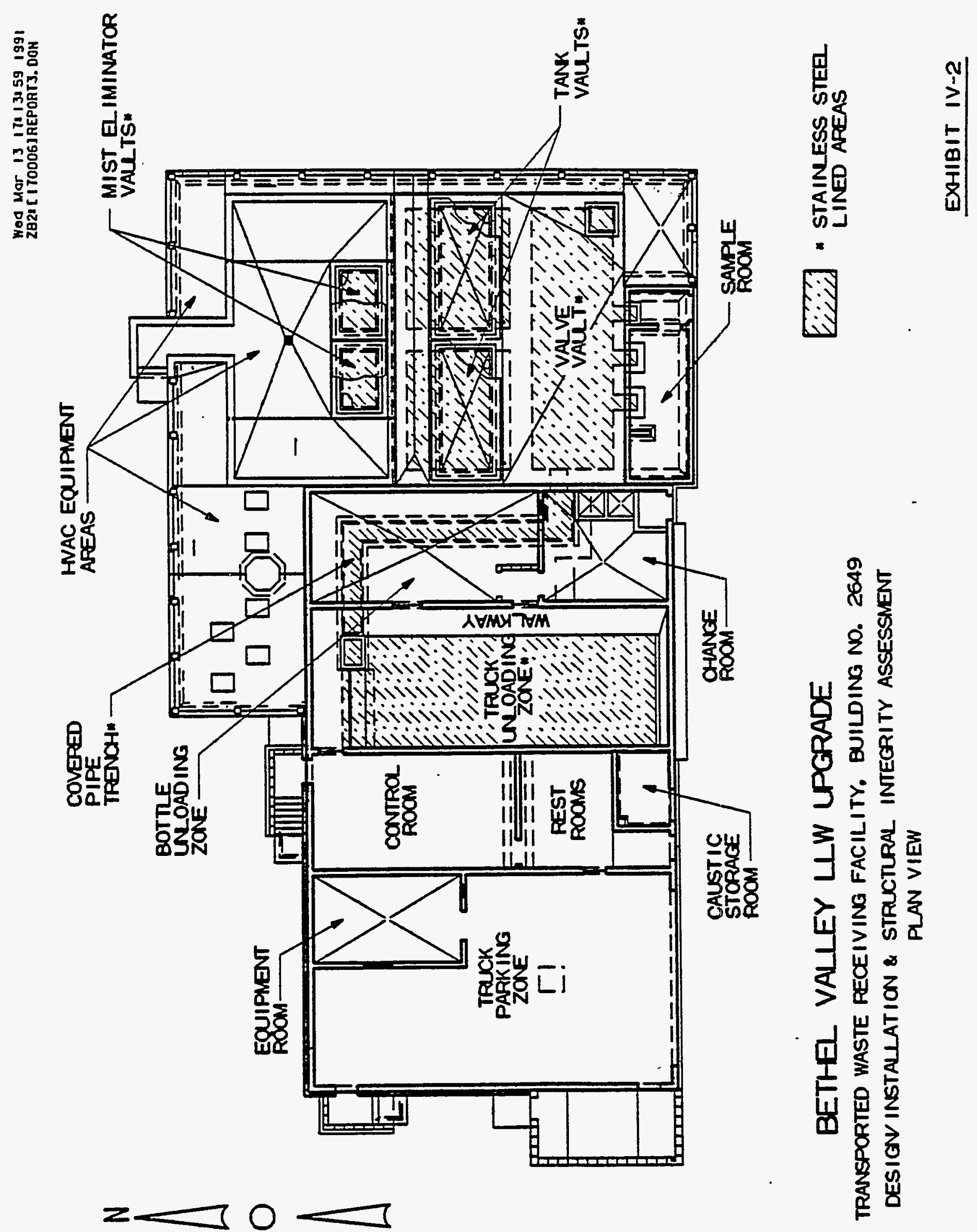




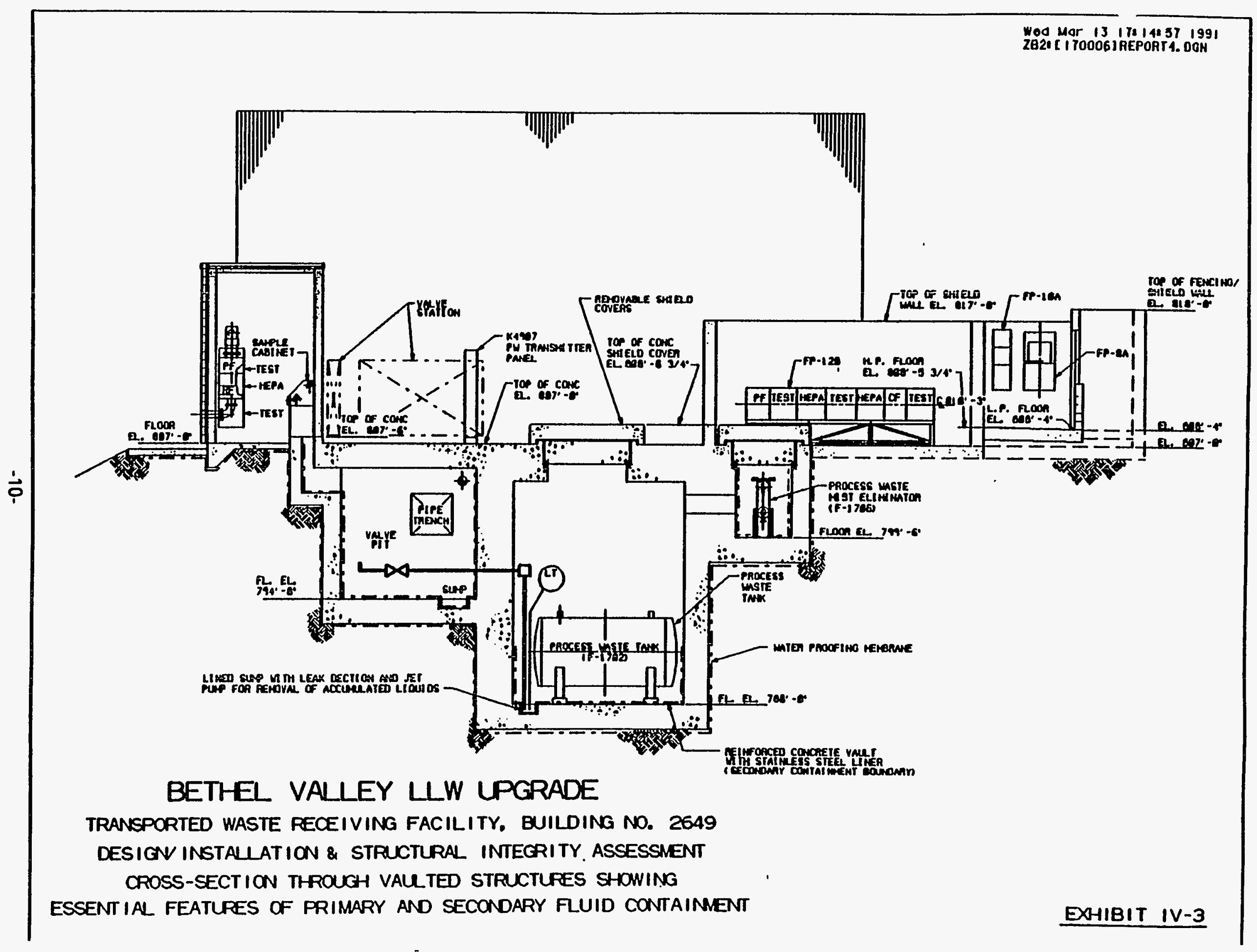


- Double wall pipe embedded in concrete or buried underground. The outer pipe fulfills the secondary containment function and is protected from corrosion by an exterior coating in conjunction with a galvanic anode type cathodic protection system. The annular space between the double wall pipe retains potential leakage from the inner, primary, waste containing pipe. The space is provided with leak detection by pressurization with nitrogen and monitoring of the annular space pressure. The annular space is divided into discrete segments and provided with test and monitoring stations to facilitate location and repair of potential leaks.

The piping runs are classified into two functional categories:

Service piping conveys LLW from the Truck Unloading Zone and the Bottle Unloading Zone to the LLW tank in the MCS portion of the TWRF.

Transfer piping conveys LLW from the LLW tank to the connection with the CWCH. The LLW tank may hold 1,100 or more gallons of waste, which is pumped in batches through the transfer line by a steam jet ejector during a transfer operation.

- A tank comprising a single wall LLW collection tank fabricated from corrosion resistant material and located in a buried underground reinforced concrete vault. The vault, which fulfills the secondary containment function, is provided with a stainless steel inner liner and a sump with a leak detection system. The vault is designed to withstand design basis natural phenomena, including seismic events and tornadoes. The PW tank is designed to the same functional requirements and standards as the LLW tank, since it may function as a backup to the LLW tank.

The overall conclusion of this assessment is that the various elements described above, which compose the entire Tank System for Building 2649, are in compliance with applicable portions of Appendix $F$ to the Federal Facility Agreement. The remaining portions of this assessment describe the means of compliance for each design feature 
and confirm the adequacy of the design for the purposes of environmental protection.

\section{B. Standards for Design/Installation of New or Replacement Tank Systems}

\section{Design/Installation Assessment}

This part of the assessment focuses on the following aspects of the replacement Tank System:

- Design standards, including codes, criteria, and specifications used by the design project for design, fabrication, and installation of the Tank System.

- Characteristics of hazardous substances to be contained by the Tank System.

- Corrosion protection provided by the design for metal components that will be in direct contact with the soil, such as the outer pipe in a double wall pipe system.

- Man-induced hazards, such as vehicular traffic.

- Natural phenomena, such as seismic events, frost heave, ground water, heavy rain and surface run-off, and potential flooding of nearby water sources (White Oak Creek).

\section{(a) Design Standards}

The applicable standards, codes, and criteria used by the design project that govern the design, fabrication, and installation of the tank systems are identified herein. The application of standards, codes, and criteria is generally performed on an engineering disciplinary basis and, therefore, the following listing is so organized. The list has been edited to minimize duplication, but certain entries are repeated if they constitute a key element in the input for a particular discipline work scope. The adequacy of these 
standards, codes, and criteria is evaluated by discipline and is correlated with specific design features when applicable.

\section{(i) Mechanical Engineering and Design}

The scope of mechanical engineering and design for the TWRF tank system includes the LLW and PW tanks, all LLWW containing piping (single and double wall), and support equipment such as the tank ventilation system.

The assessment concludes that the stanclards, codes, criteria, and specifications for the mechanical engineering aspects of the Tank System for Building 2649, are suitable and appropriate. The tank, primary and secondary piping, and other design elements are covered by codes, etc. that mandate use of appropriate materials, design, fabrication and installation, and examination and inspection procedures and techniques.

The selection of materials for the Tank System is appropriate in order to assure compatibility with the wastes to be stored. Building 2649 typically will receive moderately weak acidic liquids. The material selected for principal portions of the primary, or inner, boundary of the new LLW piping is Type $304 \mathrm{~L}$ austenitic stainless steel, which exhibits good corrosion resistance in the presence of moderately weak acids.

The LLW tank is constructed of Type $304 \mathrm{~L}$ austenitic stainless steel. The LLW tank will generally contain liquids of less acidity compared to the service piping since the incoming waste streams will mix with and be diluted by the residual liquid in the LLW tank. The design of the Tank System provides for the capability to add caustic in measured amounts to adjust the $\mathrm{pH}$ of the tank liquid. 
The transfer piping and related ancillary equipment such as steam jet ejectors, HVAC ductwork and filter housings, and vault and sump liners are also fabricated from Type 304L austenitic stainless steel. The aforementioned components will be exposed to the same liquids as will the LLW tank. Therefore, the Type 304L material selected is also satisfactory for these applications.

This portion of the assessment is valid for the design and installation of the Tank System. The design is essentially complete and is in compliance with the referenced codes, standards, and criteria. During the installation phase of the project, actions such as examinations, inspections, and tests must be undertaken to confirm that the installation remains in conformance with the design and with required codes, standards, etc.

The application of the following standards, codes, and criteria to essential elements of the design is indicated as follows:

P . - applies to primary (inner) LLW containing pipe and valves

S - applies to secondary (outer) pipe

$T$ - Applies to LLW containing tanks

\section{Codes}

American Society of Mechanical Engineers (ASME)

- NQA-1, Quality Assurance Program Requirements $T$ for Nuclear Facilities

- Boiler and Pressure Vessel Code $P, T$ Section II, Material Specifications 
(Governs materials specifications in conjunction with ASTM Standards)

- Section III, Nuclear Power Plant Components

Division 1, Subsection NB

(Used to govern procurement of piping

materials)

- Section V, Non-destructive Examination

(Governs non-destructive examination in conjunction with Section VIII)

- Section VIII, Division 1, Pressure Vessels

(Design code for tank)

- Section IX, Welding and Brazing Qualifications

(Governs qualification of welders)

American National Standards Institute (ANSI)

- B16.5, Steel Pipe Flanges and Flanged Fittings

$P, S, T$

(Governs flange pressure/temperature ratings)

- B31.3, Chemical Plant and Petroleum Refinery

P, S

Piping (Design code for LLW piping)

\section{Standards}

American Society for Testing Materials (ASTM)

- A-182, Specification for Forged or Rolled $P, S, T$ Alloy-Steel Pipe Flanges, Forged Fittings, and Valves and Parts for High Temperature Service

- A-193, Specification for Alloy-Steel and $P, S, T$ Stainless Steel Bolting Materials for High Temperature Service 
- A-194, Specification for Carbon and Alloy-Steel P, S, T Nuts for Bolts for High Pressure and High Temperature Service

- A-213, Specification for Seamless Ferritic and $S$ Austenitic Alloy-Steel Boiler-Superheater and Heat Exchanger Tubes

- A-240, Specification for Heat-Resisting Chromium and Chromium-Nickel Stainless Steel Plate, Sheet, and Strip for Pressure Vessels

- A-262, Practices for Detecting Susceptibility to $P, T$ Intergrannular Attack on Austenitic Stainless Steels

- A-312, Specification for Seamless and Welded $P, S, T$ Austenitic Chromium-Nickel Alloy Steel Pipe for High Temperature Service

- A-358, Specification for Electric-Fusion-Welded P Austenitic Chromium-Nickel Alloy Steel Pipe for High Temperature Service

- A-403, Specification for Wrought Austenitic $P, S, T$ Stainless Steel Piping Fittings

- A-479, Specification for Stainless and Heat-Resisting Steel Wire, Bars, and Shapes for Use in Boilers and Other Pressure Vessels

- D-227, Specification for Coal-Tar Saturated Organic Felt Used in Roofing and Waterproofing

- D-450, Specification for Coal-Tar Pitch Used in Roofing, Dampproofing, and Waterproofing 
- 203-86, Coal-Tar Protective Coatings and Linings S for Steel Water Pipelines - Enamel and Tape-Hot-Applied (Governs coating on secondary pipe for corrosion protection in soil)

American Welding Society

- A5.9, Specification for Corrosion Resisting P, S, T Chromium and Chromium-Nickel Steel Bare and Composite Metal Cored and Stranded Welding Electrodes and Welding Rods

- QC-1, Standard for AWS Certification of Welding $P, S, T$ inspectors

- SNT-TC-1A, Recommended Practice, American P, S, T Society for Non-destructive Testing, Inc.

- Occupational Safety and Health Administration Standards (OSHA)

- Uniform Building Code, 1988 T

- UCRL-15910, Design and Evaluation Guidelines T for DOE Facilities Subjected to Natural Phenomena Hazards

\section{(ii) Structural Engineering and Design}

The scope of structural engineering and design includes: the main TWRF building which receives the LLW by truck; the MCS portion of the TWRF including the Sampling Room; the slab and shield walls for the HVAC equipment areas; and the structural modification to Valve Box No. 3. The main TWRF Building, whose primary functions were described in Section III, is a one story building $82 \mathrm{ft}$. by $50 \mathrm{ft}$. in plan and about $22 \mathrm{ft}$. 
high. The structure consists of reinforced concrete perimeter and interior walls which serve as both bearing and shear walls. The interior floor consists of slabs on grade. The roof consists of bar joists, metal decking, and built-up roofing. The MCS portion of the TWRF consists of below grade reinforced concrete valve and tank vaults. Separate compartments are provided in the tank vault for each of the two tanks. The Sampling Room consists of a small, one story, reinforced concrete building which houses the samplers. The sampling stations are installed over short pipe chases that are integral with the valve vault structure. The reinforced concrete sampler pipe chases are stainless steel lined and slope toward the valve vault.

The HVAC equipment structures consist of slabs on grade with concrete shield walls. This area is located adjacent to the vault structures and main TWRF building.

In addition to the new Building 2649, this assessment addresses the structural modification of Valve Box No. 3 to accommodate the new LLW piping tie-in to the CWCH.

The use of the American Concrete Institute codes and standards for design and construction of the secondary containment concrete structures, as well as all of the other concrete structures, has been evaluated. Use of these codes and standards will assure high quality concrete structures consistent with the function of housing containment tanks and piping containing low level liquid wastes.

The loads and load combinations required by the Standard Building Code, ANSI A58.1, and UCRL 15910 are appropriate for the design of the concrete structures. 
The stainless steel liner provided on internal surfaces of structures that enclose LLW tanks or piping carrying LLW functions as the leak tight secondary containment barrier. The thin liner is relatively flexible compared to the heavy, reinforced concrete structures backing the liner. Any stresses introduced into the liner through compatibility with the concrete structures are minor and self-limiting in nature. The primary design considerations for the liner are material selection and the installation/inspection criteria. The ASME Code Sections and ASTM standard specifications that have been used are appropriate and will result in the required quality to assure leak-tightness.

The following standards, codes, and criteria were applied to the structural design and specifications for fabrication and installation of the structural systems.

- $\quad$ Standard Building Code 1988

- Uniform Building Code 1988 (earthquake regulations)

- American Concrete Institute

- ACl 318-83 (Revised 1986), "Building Code Requirements for Reinforced Concrete"

- ACl 301-84 (Revised 1987), "Specifications for Structural Concrete for Buildings"

- ACl 515.1R-79 (Revised 1985), "A Guide to the Use of Waterproofing, Dampproofing, Protective, and Decorative Barrier Systems for Concrete" 
- $\mathrm{ACl} 117-81$, "Standard Tolerances for Concrete Construction and Materials"

- $\quad \mathrm{ACl}$ 302.1R-80, "Guide for Concrete Floor and Slab Construction"

- $\mathrm{ACl}$ 315-80, "Details and Detailing of Concrete Reinforcement"

- $\quad \mathrm{ACl}$ 347,-78, "Recommended Practice for Concrete Formwork"

- ACI SP-4, "Formwork for Concrete"

- $\quad \mathrm{ACl}$ 303R-74 (Revised 1982), "Guide to Cast-in-Place Architectural Concrete Practice"

- $\quad$ ACl 211.1-81 (Revised 1985), "Standard Practice for Selecting Proportions for Normal, Heavyweight, and Mass Concrete"

- ACl 305R-77 (Revised 1982), "Hot Weather Concreting"

- ACl 306R-78 (Revised 1983), "Cold Weather Concreting"

- ACl 224R-80 (Revised 1984), "Control of Cracking in Concrete Structures"

- $\mathrm{ACl}$ 350R-83, "Concrete Sanitary Engineering Structures" 
- American Institute of Steel Construction

- AISC "Code of Standard Practice for Steel Buildings and Bridges," effective September 1, 1986

- "Specification for the Design, Fabrication, and Erection of Structural Steel for Buildings," Part 1, effective Nov. 1, 1978, with Supplement 1 (March 11, 1986)

- American Society For Testing Materials (ASTM) Standards

The quality and testing of materials used in the construction was addressed by reference to the appropriate ASTM standard specifications in the project specifications and by reference in project specifications to governing standards such as $\mathrm{ACl} 318$ or $\mathrm{ACl} 301$, which incorporate the applicable ASTM standard specifications.

- American Welding Society Specifications and Codes

- D1.1-88, "Structural Welding Code"

- D1.3-81, "Specification for Welding Sheet Steel in Structures"

- American Society of Mechanical Engineers Boiler and Pressure Vessel Code, 1986, including 1987 Addenda

- Section V, "Non-Destructive Examination"

- Section IX, "Qualifications Standard for Weiding and Brazing Procedures, Welders, 
Brazers, and Welding and Brazing Operations"

- American National Standards Institute

- ANSI A58.1 - 1982, "Minimum Design Loads for Buildings and Other Structures"

- Occupational Safety and Health Administration (OSHA) Regulations

- DOE Order 6430.1A, "General Design Criteria"

- UCRL 15910, "Design and Evaluation Guidelines for Department of Energy Facilities Subjected to Natural Phenomena Hazards," May, 1989 (Draft)

- Steel Deck Institute

- SDI - Publication No. 24, 1981-82 (SDI 24), "Design Manual for Composite Decks, Form Decks, and Roof Decks"

- Steel Joist Institute

- Șl, "Standard Specifications for Open Web Steel Joists, K-Series" (adopted by Steel Joist Institute Nov. 4, 1985, Revised May 19, 1987)

- Concrete Reinforcing Steel Institute MSP-1-86, "Manual of Standard Practice," 24th Edition

- American Iron and Steel Institute (AISI), "Specification for the Design of Cold-Formed Steel Structural Members," August 19, 1986 Edition

(iii) Civil/Geotechnical Design Standards

The scope of civil/geotechnical engineering and design includes establishing plans and profiles for the 
underground double wall LLW and single wall PW piping, the design and specification of final surface contours, backfill and paving, and the characterization of site soil properties for interfacing with foundation design.

The following listing presents standards, codes, and criteria that governed the civil and geotechnical engineering and design for the Bethel Valley LLW Upgrade Project. These standards, codes, and criteria provide a conservative basis for design and installation of the tank system, and provide assurance that loadings and stresses imposed upon the tank vault and the double wall buried piping will not cause collapse, rupture, or failure of these design features.

- ORNL/MMES/USDOE "Design Criteria for the Bethel Valley Liquid Low Level Waste Collection and Transfer System Upgrade Project," issued approved September, 1988

- Subsurface soil and rock condition is based on information obtained/revealed from:

- EDGe report titled "Proposed Bethel Valley Low Level Waste Project," dated June 22, 1988

- Logs of borings shown on U.S.E.R.D.A. drawings no. C-20237-YA-026-E through C-20237-YA-033E, drilled in 1958 and 1959

- Logs of borings shown on U.S.E.R.D.A. drawings no. C-20237-YA-026-E through C-20237-YA-033E, drilled in 1958 and 1959

- Logs of borings no. $117,118,119,123,124,125$ and 126, drilled in 1988 
- MMES Technical Specifications and Sample Specifications

- MMES Engineering Standards

- UCRL-15910, "Design and Evaluation Guidelines for Department of Energy Facilities Subjected to Natural Phenomena Hazards," draft dated May, 1989, for maximum ground acceleration at ground surface $(=0.32 \mathrm{~g})$ for underground LLW transfer pipelines and tank vault

- ERC/EDGe Report, "Pipe Backfill Testing, Oak Ridge Reservation, Oak Ridge, Tennessee," dated June 28, 1990

- DOE General Design Criteria (DOE 6430.1A) for design basis earthquake dynamic analysis

- UCRL-53582, Rev. 1, "Natural Phenomena Hazards Modeling Project: Seismic Hazard Models for Department of Energy Sites," dated November, 1984

- Civil/Geotechnical Construction/Installation Standards (i.e., Interface Procedures):

- Tennessee Department of Transportation "Standard Specifications for Road and Bridge Construction," March 1, 1981, with revisions and additions

- U.S. Department of Labor, Occupational Safety and Health Administration (OSHA) Standards, 29CFR 1926/1910, 1987 
- AASHTO T180-831, "Moisture-Density Relations of Soils Using a $10 \mathrm{lb} .(4.54 \mathrm{~kg})$ Rammer and an 18-in. (457 mm) Drop"

- AASHTO T191-83I, "Density of Soil In-Place by the Sand-Cone Method"

- AASHTO T204-64 (1974), "Density of Soil In-Place by the Drive Cylinder Method"

- AASHTO T205-831, "Density of Soil In-Place by the Rubber-Balloon Method"

- AASHTO T233-70, "Density of Soil In-Place by Block, Chunk, or Core Sampling"

- AASHTO T238-79, "Density of Soil and Soil-Aggregate In-Place by Nuclear Methods (Shallow Depth)"

- AASHTO T255-83, "Total Moisture Content of Aggregate by Drying"

- USDOE "Determination of Inorganic Anions in Aqueous and Solid Samples by Ion Chromatography", test method, latest approved version

(iv) Instruments and Controls Engineering and Design

The codes and standards listed below cover selected aspects of the instruments and controls scope of work for the Building 2649 portion of the Bethel Valley LLW Upgrade. These codes and standards are appropriate and adequate to govern the design and installation of design features necessary for compliance with 40CFR264, Subpart J. These design features comprise the level detection and leak detection provisions for the LLW 
tank, secondary containment vault sumps, and the annular spaces in buried double wall piping.

\section{Codes}

National Fire Protection Association (NFPA)

- NFPA 70-1990, National Electric Code (NEC)

American Welding Society (AWS)

- D1.3.81, Structural Welding Code - Sheet Steel

- D1.1.88, Structural Welding Code

\section{$\underline{\text { Standards }}$}

American National Standards Institute (ANSI)

- B16.11-80, Fittings, Socket-Welded, and Threaded

- B31.3-87, Chemical Plant and Petroleum Refinery Piping

- C2, National Electrical Safety Code

Instrument Society of America (ISA)

- ISA-S5.1-1984, Instrumentation Symbols and Identification

- ISA-S5.4-1976 (R-81), instrument Loop Diagrams

- ISA-RP7.1-1956, Pneumatic Control Circuit Pressure Test

- ISA-S12.13-1986, Performance Requirements, Combustible Gas Detectors

- ISA-S20-1981, Specification Forms for Process Measurement and Control Instruments 
- ISA-S51.1-1979, Process Instrumentation

National Electrical Manufacturer's Association (NEMA)

- 250-85, Enclosures

- 1CS-6-83, Enclosures for Industrial Controls

- 1CS-1-83, General Standards

- WC-5, Thermoplastic Insulated Wire and Cable

- WC-7, Cross-linked Thermosetting Polyethylene Insulated Wire and Cable

- WC-8, Ethylene-Propylene Rubber Insulated Wire and Cable

(v) Electrical Engineering and Design (Cathodic Corrosion Protection)

The standard listed below covers the design, installation, and testing of cathodic protection systems for buried metallic components. The use of this standard is appropriate to provide satisfactory corrosion protection for the buried double wall pipe (outer pipe in contact with soil). No tanks are directly in contact with the soil. Certain other codes and standards that are required to assure the adequate design and installation of level and leak detection systems are listed in the instruments and Controls Section. 
National Association of Corrosion Engineers

- RP-01-69, 1983, Recommended Practice - Control of External Corrosion on Underground or Submerged Metallic Piping Systems

\section{IV.B.1(b) Hazardous Substance Characteristics}

The hazardous and/or radioactive substances handied by Building 2649 and discharged to the ORNL CWCH are listed in Table B-1. This characterization is based on assessments of facility mission requirements and historical knowledge of previous waste stream properties, from facilities that will dispatch LLW to Building 2649, and is provided by Martin Marietta Energy Systems (ORNL Management and Operations Contractor) as input to this assessment.

It is expected that the waste stream analysis presented in Table B-1 is representative of the waste to be received by the tank in Building No. 2649. However, the composition of this waste stream may vary as specific experiments, analyses, and campaigns are conducted. Of principal concern for this assessment is the suitability of the material selected as the primary fluid boundary for piping exposed to unadjusted, undiluted waste. In this regard, the $\mathrm{pH}$ value as a measure of acidity and aggressiveness is of principal interest. The suitability of primary fluid boundary materials is discussed in IV.B.1.(a)(i) of this assessment.

The variations in composition of the waste stream are limited by the General Waste Acceptance Criteria, which specifies activity and concentration limits for waste discharged into the LLW system. These criteria are presented below: 


\section{Table B-1}

BETHEL VALLEY LIQUID LOW LEVEL WASTE STREAM CHARACTERIZATIONS

BUILDING 2649 - TRANSPORTED WASTE RECEIVING FACILITY

\begin{tabular}{|c|c|}
\hline Isotope & LSA Conc. $(u C i / g)$ \\
\hline Gross alpha & 0.1 \\
\hline Gross beta (no alpha) & 5 \\
\hline Am-241 & 0.1 \\
\hline Am-242 & 0.1 \\
\hline Am-243 & 0.1 \\
\hline $\mathrm{Ba}-140$ & 300 \\
\hline$C-14$ & 300 \\
\hline $\mathrm{Ce}-141$ & 300 \\
\hline$C f-252$ & 0.1 \\
\hline $\mathrm{Cm}-244$ & 0.1 \\
\hline $\mathrm{Cm}-246$ & 0.1 \\
\hline Co-60 & 300 \\
\hline $\mathrm{Cr}-51$ & 300 \\
\hline Cs-134 & 300 \\
\hline Cs-137 & 300 \\
\hline $\mathrm{Cu}-67$ & 300 \\
\hline Eu-152 & 300 \\
\hline Eu-154 & 300 \\
\hline Eu-155 & 300 \\
\hline Fe-59 & 300 \\
\hline Gd-153 & 300 \\
\hline$H-3$ & 5000 \\
\hline $1-123$ & 300 \\
\hline $1-125$ & 300 \\
\hline $1-129$ & 300 \\
\hline $1-131$ & 300 \\
\hline $\mid r-192$ & 300 \\
\hline $\mathrm{Kr}-85$ & 300 \\
\hline MixfP & 300 \\
\hline Mn-54 & 300 \\
\hline
\end{tabular}


Table B-1

BETHEL VALLEY LIQUID LOW LEVEL WASTE

STREAM CHARACTERIZATIONS

BUILDING 2649 - TRANSPORTED WASTE RECEIVING FACILITY

\begin{tabular}{lc} 
Isotope & LSAConc. (uCi/g) \\
\hline Os-191 & 300 \\
Pu-238 & 0.1 \\
Pu-239 & 0.1 \\
Pu-240 & 0.1 \\
Pu-241 & 5 \\
Re-188 & 300 \\
Ru-103 & 300 \\
Ru-106 & 300 \\
Sc-46 & 300 \\
Sr-90 & 5 \\
Tc-99 & 300 \\
Th-228 & 0.1 \\
Th-232 & uni \\
U-232 & 0.1 \\
U-233 & 5 \\
U-235 & 5 \\
U-238 & 500 \\
W-181 & unl \\
W-188 & 300 \\
Zn-65 & 300 \\
Zr/Nb-95 & 300 \\
& 300 \\
&
\end{tabular}

LSA - Low Specific Activity

unl - Unlimited

Note 1: Isotopes not listed above may be present in trace quantities, or have been identified as not being present at all in ORNL LLLW.

Note 2 : The limits specified for Gross Beta and for Mixed Fission Products are based on the limits for Sr-90. The Gross Beta and MFP limits do not apply in cases where isotopic analysis has identified the specific isotopes present. 


\section{Waste Acceptance Criteria}

The LLW system should be used to collect and treat all solutions containing radioactivity above the levels listed in Table B-2, with the following provisions:

- Liquid radioactive wastes added to the LLW system must not have an activity concentration exceeding $5 \times 1010 \mathrm{~Bq} / \mathrm{L}$ (5ci/gal).

- Solutions containing $233 \mathrm{U}, 235 \mathrm{U}, 235 \mathrm{Pu}$, or $241 \mathrm{Pu}$ must be mixed with depleted uranium or natural thorium so that the resultant solution will contain at least 100 parts by weight of $238 \mathrm{U}$ or 232Th per part by weight of the fissile isotope(s).

- Solutions containing TRU isotopes of $233 U$ that are added to the LLW system must not have a total specific activity from those nuclides greater than $3.7 \times 106 \mathrm{~Bq} / \mathrm{kg}$ $(100 \mathrm{nCi} / \mathrm{g})$.

- Beta-gamma emitting waste greater than $5 \times 1010 \mathrm{~Bq} / \mathrm{L}$ ( $5 \mathrm{Ci} / g a l$ ) and high toxicity alpha and TRU waste greater than $3.7 \times 106 \mathrm{~Bq} / \mathrm{kg}(100 \mathrm{nCi} / \mathrm{g})$ must be diluted to levels below those limits prior to discharge.

- Before disposing of liquid waste containing reportable nuclear material, the generator must execute Form UCN-6073 to request and receive permission from the Special Materials Management Department. Reportable quantities of nuclear material are listed in Health Physics Procedure 5.3, page 7, Table 2. The generator prepares Form UCN-2681 to complete the transfer of the reportable nuclear material to either the Liquid and Gaseous Waste Operations Department or the Solid Waste Operations Department. 
GROSS ALPHA

GROSS BETA

Sr-90

Cs-137

Co-60

Eu-152

Eu-154

Eu-155

Ru-106

ZrNb-95
$10 \mathrm{~Bq} / \mathrm{L}$

$10,000 \mathrm{~Bq} / \mathrm{L}$

$10,000 \mathrm{~Bq} / \mathrm{L}$

$400 \mathrm{~Bq} / \mathrm{L}$

$185 \mathrm{~Bq} / \mathrm{L}^{*}$

$740 \mathrm{~Bq} / \mathrm{L}^{*}$

$740 \mathrm{~Bq} / \mathrm{L}^{*}$

$3700 \mathrm{~Bq} / \mathrm{L}^{*}$

$222 \mathrm{~Bq} / \mathrm{L}$ *

$1,480 \mathrm{~Bq} / \mathrm{L}^{*}$

* DOE Order 5400.5 DCG Values 
LLW, which also contains toxic materials (PCB's, mercury, etc.), should not be discharged to the LLW system (unless a waiver is granted by Waste Management Operations), but should be transferred to the Hazardous Waste Operations Group for storage until its uitimate disposition is determined. Organic solvents or organic chemicals contaminated with radioactivity may be discharged into LLW drains provided the primary hazard of concern is radioactivity. Sanitary waste must not be discharged to the LLW system unless a medical emergency exists.

No new LLW streams greater than $15 \mathrm{gpd}$ in volume are to be added without the permission of the Liquid Waste LCO.

\section{IV.B.1(c) Corrosion Protection}

The new Tank System design for Building 2649 does not expose the external shell of any metal tanks to direct contact with the soil or with water. As noted previously, the waste (LLW and PW) tanks are located in underground, lined, concrete vaults. However, a significant amount of buried piping constitutes an important part of the design. This buried piping is in direct contact with a backfill material selected to provide favorable design properties, as discussed in Section IV.B.4 and IV.B.6 of this assessment.

Norton Corrosion Limited, Inc., under subcontract to the Architect/Engineer, has reviewed original soil data (provided by Martin Marietta Energy Systems), engineered backfill characteristics, pertinent design drawings and specifications, and design calculations to ensure pertinent criteria have been met. This includes providing a system that requires minimal maintenance and meets the design criteria life requirements. The specific criteria used have been assessed with the results as follows: 
Soil data was reviewed and offered an adequate representation of the soil characteristics throughout the piping routes. In addition, characteristics of the piping backfill were provided and included in the design calculations. This design provides relatively controlled environmental conditions, due to the use of an engineered backfill material to be installed in a prescribed manner. This increases the confidence level in the expected performance of the entire corrosion protection system.

A review of pertinent electrical drawings was conducted to determine possible sources of potentially damaging current interference. This includes high voltage power lines, other cathodic protection systems, or dc power sources. The results of this review found no immediate concerns. It should be noted that the post-installation testing will test for current interference.

\section{(ii) External Corrosion Protection}

A number of corrosion control measures have been implemented. Specifically, the outer (secondary) containment pipe of the double wall LLW pipe system utilizes a 304-L stainless steel alloy. In addition, a high dielectric coating will be applied to isolate the piping from the backfill and surrounding soil. Since no coating system is $100 \%$ effective, a galvanic cathodic protection system is provided to protect any exposed metal. A review of these systems found that they are properly designed and meet all design criteria.

Electrical isolation of the piping is provided to maintain the integrity of the corrosion control systems. This includes isolation of the new piping from new and 
existing structures, leak monitoring equipment, and concrete vault penetrations. The materials and methods used include flange isolation kits and non-metallic grounding cells provided at all isolation flanges to prevent hazardous shorting conditions from developing.

In order to test and confirm the proper operation of the cathodic protection system following installation, a number of test stations are provided. These test stations utilize copper-copper sulfate reference electrodes, which provide a reference for the measurement of electric potentials between the pipe and the soil (backfill). The performance of the cathodic protection system shall be checked and documented after installation by an N.A.C.E. certified engineer.

Final design calculations (Ref: DC-5350-106-E01) indicate a life expectancy of 162 years, compared to the original design criteria requirement of 25 years. Therefore, this assessment concludes that the corrosion protection system employed for the outer pipe of the buried double. wall piping is satisfactory for its intended purpose.

\section{IV.B.1(d) Vehicular Traffic Protection}

(i) MCS Portion of the TWRF (vaulted structures)

A new asphalt paved area will extend to approximately 3 feet from the outside of the east wall of the reinforced concrete tank vault pit. Conservatively assuming a $45^{\circ}$ zone of influence and an $\mathrm{H} 2 \mathrm{O}$ truck live load located 4 feet from the tank vault pit wall, this concentrated wheel load would locally influence the wall at a minimum depth of 4 feet by imposing a vertical surcharge load of approximately 200 psf. This will be the maximum value and would be locally imposed th the east side of the tank vault pit. The vertical surcharge load 
would vary, with a minimum value occurring at the bottom of the pit, of approximately 20 psf. The tank vault walls are designed for a uniformly distributed surcharge load of $250 \mathrm{psf}$, placed over the entire ground surface at the walls. Thus, the uniformly distributed design load exceeds the locally concentrated vehicular wheel load described above, as well as vehicular loads anticipated during construction.

(ii) LLW Underground Piping

The radiation shielding requirement necessitates a minimum earth cover of 3 feet above all LLW underground piping. Therefore, the piping is designed for a vertical load on the pipe equivalent to at least 6 feet of soil, which is twice the minimum earth cover.

The backfill around the pipe will consist of sand-bentonite mixture placed in 6-inch layers and compacted using light (hand-held) compaction equipment.

As the (outer) pipe diameter of 4 inches is small compared to the minimum 3-foot embedment and as the pipe wall will be Schedule 10 stainless steel, the pipe can be considered flexible with respect to the compact backfill around it. Also, due to the pipe flexibility and small diameter, the load imposed on it due to vehicular traffic at grade surface will be negligible. Due to light compaction equipment, the vertical load(s) imposed on the pipe will be smaller during construction than the design load. Thus, the pipe is designed conservatively with respect to vehicular or equipment loads during or after construction. 


\section{IV.B.1(e) Design Considerations}

(i) The tanks are housed in an underground reinforced concrete vault structure. The tank foundation consists of a $39 \mathrm{ft}$. by $19 \mathrm{ft}$. by $2 \mathrm{ft}$. thick reinforced concrete vault base slab.

The tank vault arrangement has the bottom of the base slab approximately 23 feet below finished grade. The base slab is founded on rock. A concrete mudmat is provided over the rock to accept the base slab. Due to the below grade embedment of the tank vault, the net maximum bearing pressure on the rock is less than $1 \mathrm{ksf}$, well within the permissible bearing capacity of the rock. Due to the very low vault bearing pressure relative to the rock bearing capacity, settlement of the tank vault is expected to be insignificant.

The assessment concludes that the tank foundation is conservatively designed to maintain the load of both tanks full to capacity.

(ii) Each tank design includes the provision of anchorage for the tank to the base slab. The anchorage has been designed for two loading conditions: seismic loading assuming the tank is full, which is the controlling seismic condition, and flotation or buoyancy forces on the tank assuming the tank is empty and the tank vault is filled with water.

Each tank is provided with two saddle supports. Each saddle is attached to a separate base plate that is anchored to the base slab. The base plate also functions as part of the secondary containment liner.

The loadings, load combinations, and permissibles for seismic conditions comply with UCRL 15910 for the high 
hazard classification. The maximum horizontal ground surface acceleration used in the design is $0.32 \mathrm{~g}$, which corresponds to a hazard annual probability of exceedance of $2 \times 10-4$ for ORNL (Ref UCRL 15910, Table 4-3). Since the tank is anchored to the base slab of the below grade vault, seismic loads for the design of the tank anchorage correspond to use of the peak value from the median centered Newmark and Hall response spectrum for a competent soil site anchored at $0.32 \mathrm{~g}$, assuming $5 \%$ equipment damping. The resulting peak

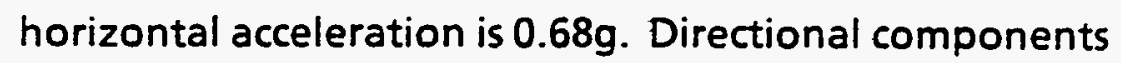
are combined by using the maximum response in one direction plus $40 \%$ of the maxima from the other two directions. In addition, UCRL 15910 permits use of $80 \%$ of the motion from the second horizontal direction and $60 \%$ of the peak acceleration for the vertical direction when peak response spectra accelerations are used. The anchors are designed in compliance with $\mathrm{ACl} 349$ Appendix B, "Steel Embedments," to assure a ductile failure mode. This design has been evaluated and found to comply with the pertinent standards, UCRL 15910 and UCRL 53582.

The assessment concludes that the LLW tank is adequately anchored to prevent flotation or dislodgement due to the potential intrusion of water into the tank vaults or the occurrence of postulated seismic events.

Buried LLW piping is provided with a minimum equivalent of 3 feet of soil overburden, which provides sufficient net downward force on the 4-inch diameter pipe to preclude flotation of the LLW pipe, conservatively assuming that the pipe is buried within a saturated zone. 
The buried LLW piping is routed flexibly to minimize the effects of building displacements and seismic soil strains that result from the propagation of compression, shear, and body waves associated with the design earthquake. The restraining effects of the compacted backfill and the beneficial effects of friction at the pipe/soil interface are considered conservatively in order to calculate the combined bending and axial stresses in buried elbows and branch connections and to demonstrate that the stress levels are within the limits set by ASME B31.3.

The assessment concludes that the buried double wall piping is designed to preclude displacement or damage due to the presence of groundwater or the occurrence of seismic events.

(iii) The tank vault is embedded approximately 23 feet below finished grade and is founded on rock. The average annual frost penetration, according to the Standard Building Code, is less than 10 inches for the ORNL. Therefore, frost heave will not affect the tank vault.

Similarly, all LLW pipes are buried with a minimum equivalent of 3 feet of soil overburden over the pipe and, therefore, are also unaffected by frost.

\section{IV.B.2. Tank Systems Installation}

The procedure for handling buried double wall pipe and the LLW and PW tanks, from the time of receipt on site, up to and including lowering of the piping into the trench and lowering the tanks into the tank vaults, will be reviewed by a qualified installation inspector. During fabrication and construction of the Tank System, primary inspection of welds in tanks, piping, liners, etc. will be performed by MMES AWS-Certified welding inspectors. Inspection of concrete, rebar, waterproofing, etc. will be performed by qualified MMES construction engineers. 
The installation inspector will observe the installation of the piping and tanks and will visually inspect the completed installation for the presence of weld breaks, punctures, scrapes of protective coatings, cracks, corrosion, or other structural damage or inadequate construction/installation. Design engineers from MMES and the Architect/Engineer (Gilbert/Commonwealth, Inc.) will consult with construction engineers, MMES QA personnel, and construction personnel, and will audit installation records to confirm compliance with design provisions.

The detection and remediation of scrapes of protective coatings applies to the coating provided on the outside of the secondary (outer) pipe. The procedure aimed at assuring the integrity of this coating system is based on the requirement of a visual holiday inspection just prior to lowering the pipe into the excavation. Defects will be repaired and rechecked prior to final installation and backfill of the pipe.

It should be noted that due to the provision of a cathodic protection system for pipe buried in soil (engineered backfill), (see Sections B.1(C), B7, and B.8 of this assessment), the presence of small. defects in the coating system, although not desirable, will not compromise the long term integrity of the system.

The remainder of this section summarizes the measures that must be undertaken during the fabrication, installation, and testing of the Tank System prior to placing the system in service. These measures are included in the technical specifications governing the design, fabrication, and installation of the Tank System and are presented in summary form in the following Installation Assessment Summary. 
INSTALLATION ASSESSMENT SUMMARY

\begin{tabular}{|c|c|c|}
\hline $\begin{array}{c}\text { Assessment Action } \\
\text { Required }\end{array}$ & By Whom & When \\
\hline $\begin{array}{l}\text { Approve subgrades/ } \\
\text { bottom of excavations for } \\
\text { building and tank vault } \\
\text { foundations. }\end{array}$ & $\begin{array}{l}\text { MMES } \\
\text { Construction } \\
\text { Engineer }\end{array}$ & $\begin{array}{l}\text { Prior to placing fill or } \\
\text { mud mat over subgradel } \\
\text { bottom of excavation. }\end{array}$ \\
\hline $\begin{array}{l}\text { Approve subgrades for } \\
\text { slabs, pipe, and pavements }\end{array}$ & $\begin{array}{l}\text { MMES } \\
\text { Construction } \\
\text { Engineer }\end{array}$ & $\begin{array}{l}\text { Prior to placing any fill } \\
\text { over subgrade. }\end{array}$ \\
\hline $\begin{array}{l}\text { Review results of backfill } \\
\text { density, moisture, and } \\
\text { chloride/sulfate content } \\
\text { laboratory tests. }\end{array}$ & $\begin{array}{l}\text { MMES } \\
\text { Construction } \\
\text { Engineer }\end{array}$ & $\begin{array}{l}\text { Prior to placing backfill } \\
\text { around buried pipe and } \\
\text { beneath or around below } \\
\text { grade structures. }\end{array}$ \\
\hline $\begin{array}{l}\text { Observe backfill mixing } \\
\text { and placement. }\end{array}$ & $\begin{array}{l}\text { MMES } \\
\text { Construction } \\
\text { Engineer }\end{array}$ & $\begin{array}{l}\text { During mixing and } \\
\text { placement of backfill } \\
\text { around buried pipe and } \\
\text { beneath or around below } \\
\text { grade structures. }\end{array}$ \\
\hline $\begin{array}{l}\text { Review results of in-place } \\
\text { density and moisture } \\
\text { content tests for } \\
\text { subgrades and backfills. }\end{array}$ & $\begin{array}{l}\text { MMES } \\
\text { Construction } \\
\text { Engineer }\end{array}$ & $\begin{array}{l}\text { As required and during } \\
\text { placement of fill. }\end{array}$ \\
\hline $\begin{array}{l}\text { Review certification } \\
\text { documents for concrete } \\
\text { and associated materials } \\
\text { including: cement, } \\
\text { aggregates, admixtures, } \\
\text { water, unit weight of } \\
\text { concrete, curing } \\
\text { compound, form release } \\
\text { agent, concrete sealer, } \\
\text { concrete hardener/sealer, } \\
\text { grout. }\end{array}$ & $\begin{array}{l}\text { MMES Design } \\
\text { Engineer }\end{array}$ & $\begin{array}{l}\text { Prior to initial concrete } \\
\text { production. }\end{array}$ \\
\hline $\begin{array}{l}\text { Review concrete mix } \\
\text { design test reports. }\end{array}$ & $\begin{array}{l}\text { MMES Design } \\
\text { Engineer }\end{array}$ & $\begin{array}{l}\text { Prior to initial concrete } \\
\text { production. }\end{array}$ \\
\hline $\begin{array}{l}\text { Review test results for } \\
\text { chloride content in } \\
\text { concrete. }\end{array}$ & $\begin{array}{l}\text { MMES Design } \\
\text { Engineer }\end{array}$ & $\begin{array}{l}\text { Prior to initial concrete } \\
\text { production. }\end{array}$ \\
\hline
\end{tabular}




\section{INSTALLATION ASSESSMENT SUMMARY}

\begin{tabular}{|c|c|c|}
\hline $\begin{array}{c}\text { Assessment Action } \\
\text { Required }\end{array}$ & By Whom & When \\
\hline $\begin{array}{l}\text { Review concrete supplier's } \\
\text { current NRMCA } \\
\text { certification. }\end{array}$ & $\begin{array}{l}\text { MMES Design } \\
\text { Engineer }\end{array}$ & $\begin{array}{l}\text { Prior to initial concrete } \\
\text { production. }\end{array}$ \\
\hline Review batch tickets. & $\begin{array}{l}\text { MMES } \\
\text { Construction } \\
\text { Engineer }\end{array}$ & $\begin{array}{l}\text { After each day of } \\
\text { concrete placement. }\end{array}$ \\
\hline $\begin{array}{l}\text { Review concrete pre- } \\
\text { placement inspection } \\
\text { forms, and composite } \\
\text { opening and embedment } \\
\text { schedules. }\end{array}$ & $\begin{array}{l}\text { MMES } \\
\text { Construction } \\
\text { Engineer }\end{array}$ & $\begin{array}{l}\text { Prior to each concrete } \\
\text { placement. }\end{array}$ \\
\hline $\begin{array}{l}\text { Review certifications for } \\
\text { reinforcing steel material } \\
\text { and gasket material for } \\
\text { access hatches. }\end{array}$ & $\begin{array}{l}\text { MMES Design } \\
\text { Engineer }\end{array}$ & Prior to installation. \\
\hline $\begin{array}{l}\text { Inspect reinforcing steel } \\
\text { for grade, number, size, } \\
\text { spacing of bars; adequacy } \\
\text { of support ties, splices; } \\
\text { clearances to formwork, } \\
\text { subgrade, and between } \\
\text { bars; cleanliness. }\end{array}$ & $\begin{array}{l}\text { MMES } \\
\text { Construction } \\
\text { Engineer }\end{array}$ & $\begin{array}{l}\text { Prior to each concrete } \\
\text { placement. }\end{array}$ \\
\hline $\begin{array}{l}\text { Review shop detail and } \\
\text { installation drawings for } \\
\text { stainless liners, gaskets, } \\
\text { reinforcing steel, and } \\
\text { membrane waterproofing. }\end{array}$ & $\begin{array}{l}\text { MMES Design } \\
\text { Engineer }\end{array}$ & Prior to fabrication. \\
\hline $\begin{array}{l}\text { Review qualification } \\
\text { certifications of } \\
\text { procedures and welders to } \\
\text { ASME Code Section IX } \\
\text { requirements for stainless } \\
\text { steel liners. }\end{array}$ & $\begin{array}{l}\text { MMES } \\
\text { Quality Dept. } \\
\text { (AWS } \\
\text { Qualified } \\
\text { Weld } \\
\text { Inspector) }\end{array}$ & $\begin{array}{l}\text { Prior to performance of } \\
\text { work. }\end{array}$ \\
\hline $\begin{array}{l}\text { Review installation } \\
\text { instructions for gaskets } \\
\text { and membrane } \\
\text { waterproofing. } \\
\end{array}$ & $\begin{array}{l}\text { MMES Design } \\
\text { Engineer }\end{array}$ & Prior to field installation. \\
\hline $\begin{array}{l}\text { Review manufacturer } \\
\text { certification of membrane } \\
\text { waterproofing applicator. }\end{array}$ & $\begin{array}{l}\text { MMES Design } \\
\text { Engineer }\end{array}$ & $\begin{array}{l}\text { As part of acceptance of } \\
\text { proposed waterproofing } \\
\text { system. }\end{array}$ \\
\hline
\end{tabular}




\section{INSTALLATION ASSESSMENT SUMMARY}

\begin{tabular}{|c|c|c|}
\hline $\begin{array}{c}\text { Assessment Action } \\
\text { Required }\end{array}$ & By Whom & When \\
\hline $\begin{array}{l}\text { Certification of membrane } \\
\text { waterproofing adherence } \\
\text { test to concrete substrate. }\end{array}$ & $\begin{array}{l}\text { MMES Design } \\
\text { Engineer }\end{array}$ & Prior to field installation. \\
\hline $\begin{array}{l}\text { Review the results of the } \\
\text { concrete compressive } \\
\text { strength cylinder break test. }\end{array}$ & $\begin{array}{l}\text { MMES } \\
\text { Construction } \\
\text { Engineer }\end{array}$ & $\begin{array}{l}\text { Within one week after } \\
\text { results are submitted. }\end{array}$ \\
\hline $\begin{array}{l}\text { Review the results of slump, } \\
\text { air content, and } \\
\text { temperature tests. }\end{array}$ & \begin{tabular}{|l|} 
MMES \\
Construction \\
Engineer
\end{tabular} & $\begin{array}{l}\text { Daily during concrete } \\
\text { placement. }\end{array}$ \\
\hline $\begin{array}{l}\text { Review Certified Material } \\
\text { Test Reports submitted by } \\
\text { supplier of piping materials } \\
\text { for primary and secondary } \\
\text { piping, steam jet ejectors, } \\
\text { and vault liner materials. }\end{array}$ & $\begin{array}{l}\text { MMES } \\
\text { Quality Dept. } \\
\text { personnel }\end{array}$ & $\begin{array}{l}\text { Upon receipt, prior to } \\
\text { fabrication and } \\
\text { installation of piping, } \\
\text { liners, etc. }\end{array}$ \\
\hline $\begin{array}{l}\text { Review Certified Material } \\
\text { Test Reports submitted by } \\
\text { LLW and PW tank vendor. }\end{array}$ & $\begin{array}{l}\text { MMES } \\
\text { Quality Dept. } \\
\text { personnel }\end{array}$ & $\begin{array}{l}\text { Prior to start of tank } \\
\text { fabrication. }\end{array}$ \\
\hline $\begin{array}{l}\text { Review piping and vault } \\
\text { liner weld examination } \\
\text { records (required per Tables } \\
\text { B.3-1 and B.3-2). }\end{array}$ & $\begin{array}{l}\text { MMES } \\
\text { Quality Dept. }\end{array}$ & $\begin{array}{l}\text { Ongoing during } \\
\text { installation of piping and } \\
\text { vault liners. To be } \\
\text { complete prior to } \\
\text { conducting pressure test } \\
\text { for any segment of } \\
\text { piping and prior to } \\
\text { installing tank in vault. }\end{array}$ \\
\hline $\begin{array}{l}\text { Review LLW and PW tank } \\
\text { weld examination records } \\
\text { (per Tables B.3-1 and B.3-2). }\end{array}$ & $\begin{array}{l}\text { MMES } \\
\text { Quality Dept. }\end{array}$ & $\begin{array}{l}\text { Following completion of } \\
\text { tank fabrication, prior to } \\
\text { ASME Code pressure test. }\end{array}$ \\
\hline $\begin{array}{l}\text { Review piping pressure test } \\
\text { records (refer to Section } \\
\text { IV.B.5 of this assessment). }\end{array}$ & $\begin{array}{l}\text { MMES } \\
\text { Quality Dept. }\end{array}$ & $\begin{array}{l}\text { Following completion of } \\
\text { pressure test, prior to } \\
\text { covering pipe in pipe } \\
\text { trench or pouring } \\
\text { concrete (for embedded } \\
\text { pipe). May be } \\
\text { accomplished by segment } \\
\text { or portion of piping } \\
\text { system that can be } \\
\text { isolated. }\end{array}$ \\
\hline
\end{tabular}


INSTALLATION ASSESSMENT SUMMARY

\begin{tabular}{l|l|l}
\multicolumn{1}{c|}{$\begin{array}{c}\text { Assessment Action } \\
\text { Required }\end{array}$} & By Whom & \\
\hline $\begin{array}{l}\text { Review LLW and PW tank } \\
\text { pressure test records. }\end{array}$ & $\begin{array}{l}\text { MMES } \\
\text { Quality Dept. }\end{array}$ & Prior to shipment. \\
\hline $\begin{array}{l}\text { Review Form U-1, } \\
\text { Manufacturers Data } \\
\text { Report For Pressure } \\
\text { Vessels. }\end{array}$ & $\begin{array}{l}\text { MMES } \\
\text { Quality Dept. }\end{array}$ & Prior to Shipment. \\
\hline $\begin{array}{l}\text { Conduct final visual } \\
\text { inspection of LLW pipe } \\
\text { system, LLW and PW tanks } \\
\text { and vault liners (inspect } \\
\text { for weld breaks, } \\
\text { punctures, scrapes of } \\
\text { protective coatings, cracks, } \\
\text { corrosion, or other } \\
\text { structural damage or } \\
\text { inadequate } \\
\text { construction/installation). }\end{array}$ & $\begin{array}{l}\text { MMES } \\
\text { Quality Dept. }\end{array}$ & $\begin{array}{l}\text { Prior to backfill of pipe } \\
\text { segment(s) and prior to } \\
\text { lowering tank into vault } \\
\text { and installing vault } \\
\text { cover. }\end{array}$ \\
$\begin{array}{l}\text { Inspection of cathodic } \\
\text { protection system for } \\
\text { buried piping - Includes } \\
\text { visual confirmation of } \\
\text { anode wire placement in } \\
\text { pipe trench, continuity } \\
\text { tests of cathodic } \\
\text { protection circuits, } \\
\text { measurement of pipe to } \\
\text { soil potentials. }\end{array}$ & $\begin{array}{l}\text { N.A.C.E. } \\
\text { qualified } \\
\text { corrosion } \\
\text { expert }\end{array}$ & $\begin{array}{l}\text { Prior to backfill of pipe } \\
\text { trench (pipe to soil } \\
\text { potential measured after } \\
\text { backfilling). }\end{array}$ \\
& & \\
& & \\
& &
\end{tabular}




\section{INSTALLATION ASSESSMENT SUMMARY}

\begin{tabular}{|c|c|c|}
\hline $\begin{array}{c}\text { Assessment Action } \\
\text { Required }\end{array}$ & By Whom & When \\
\hline $\begin{array}{l}\text { Witness or review } \\
\text { documented results of } \\
\text { functional testing for Tank } \\
\text { System support } \\
\text { equipment, including: } \\
\text { - Level instrumentation } \\
\text { in sumps and tanks } \\
\text { - Pressure } \\
\text { instrumentation for } \\
\text { double-wall piping } \\
\text { annular space } \\
\text { - Steam jet ejector } \\
\text { capability to remove } \\
\text { liquid from sumps and } \\
\text { tanks } \\
\text { - Combustible gas } \\
\text { detector operation } \\
\text { - LLW and PW tank and } \\
\text { vault ventilation } \\
\text { system }\end{array}$ & $\begin{array}{l}\text { MMES } \\
\text { Design } \\
\text { Engineer }\end{array}$ & $\begin{array}{l}\text { Prior to placing Tank } \\
\text { System into } \\
\text { contaminated service. }\end{array}$ \\
\hline
\end{tabular}




\section{IV.B.3. Inspection Reports}

The installation of the Building 2649 Tank System utilizes a comprehensive and stringent set of inspections to assure the leak-tight integrity of the Tank System, following installation. These include inspections of shop and field welds in LLW primary and secondary piping and in the stainless steel vault liners, in accordance with Table B.3-1. The tanks are designed, fabricated, and stamped in accordance with the ASME Boiler and Pressure Vessel Code, Section VIII, Div. 1. This code requires qualified and documented weld examination procedures. The installation assessment will include reviews of weld examination records, pressure test records, material certifications, ASME code data forms, and on-site walkdowns and visual inspections of essential portions of the Tank System.

The weld examinations noted above, in conjunction with a thorough visual examination of the entire system, provide assurance that potential weld breaks, punctures, cracks, and corrosion will be detected and remedial work undertaken prior to closure of the system, i.e., embedding in concrete, burial in fill, or installation of cover slabs. Welding inspectors shall be certified by AWS QC- 1 .

MMES will maintain a retrievable file of inspection reports, test records, and other pertinent documentation. A listing of required inspection reports follows in Table B.3-2. These reports, records, etc. will be reviewed, on a statistical sample basis, by the Installation Assessment Team, to assure that acceptable welds have been produced. 
TABLE B.3-1

ATTACHMENT 1. WELD INSPECTION SUMMARY

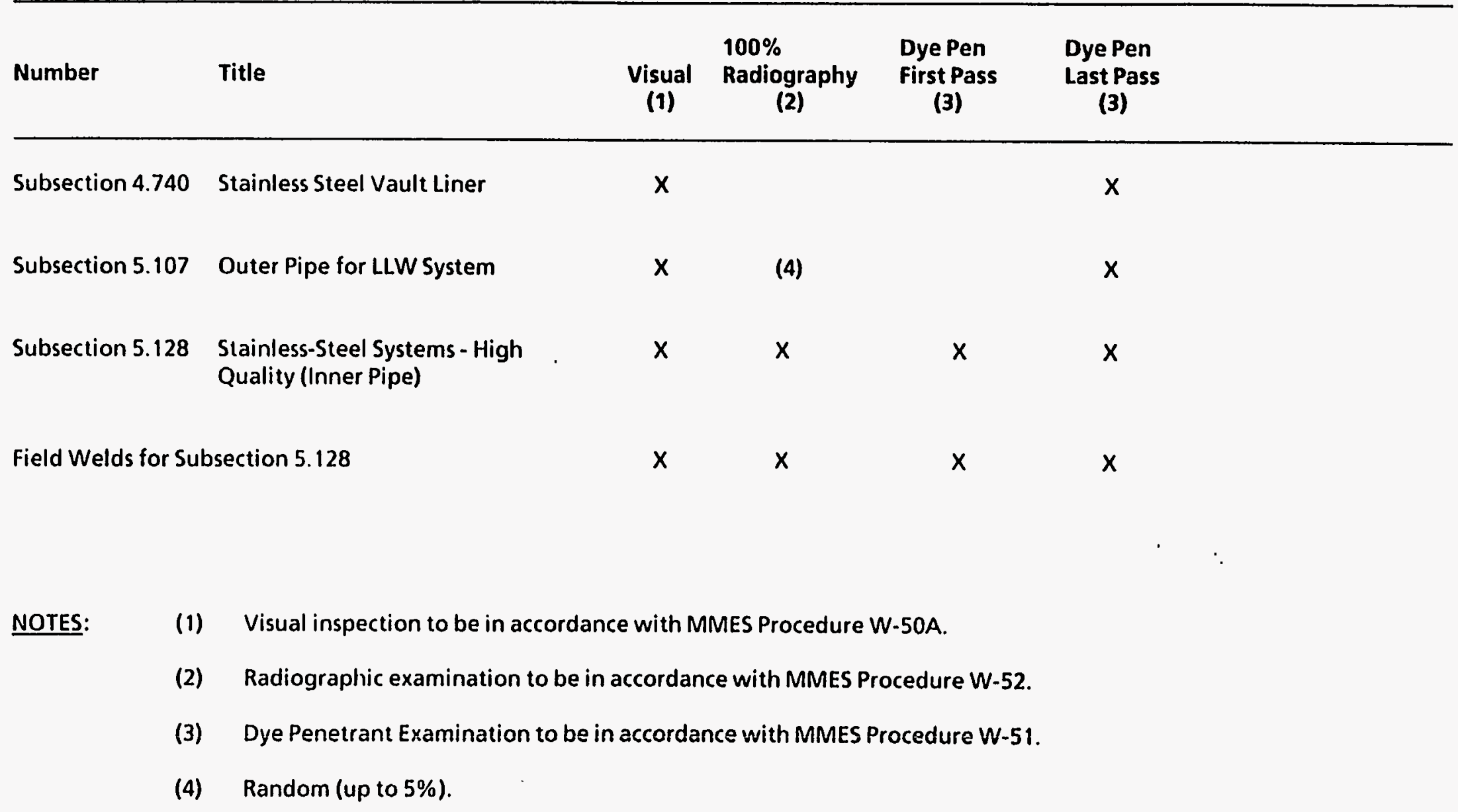




\section{INSPECTION REPORT}

Piping Welds

Visual Inspection

$100 \%$ Radiography

Dye Penetrants, First and Last Pass

Piping, Fittings, and Flanges (Liquid Penetrant)

Secondary Pipe

Primary Pipe Stainless Steel

Piping (Ultrasonic)

Primary Pipe Stainless Steel

5.128, Paragraph 2.E.3)
SPEC. REFERENCE

5.100, Attachment 1

5.100, Attachment 1

5.100, Attachment 1
5.107, Paragraph 2.E

5.128, Paragraph 2.E.2)

LLW and PW Tanks

Radiography of Welds

Longitudinal and Circumferential Butt Welds

9.101, Paragraph 9.A.a

Dye Penetrant Exam of Welds

Nozzle to Shell, Nozzle to Head Welds

9.101, Paragraph 9.A.6

Welds of Appurtenances, Lifting Lugs, Supports to Tank Shell

9.101, Paragraph 9.A.C

Vault Liner Welds

Visual Inspection

4.740, Paragraph $8 \mathrm{~A}$

Dye Penetrant, Last Pass 4.740 , Paragraph 8B 


\section{IV.B.4. Backfilling}

- TWRF:

Backfill around the reinforced concrete tank vault will be stabilized aggregate base course. This will consist of a premixed base material of crushed stone, binder material, and water, meeting the requirements of the Tennessee Department of Transportation "Standard Specifications for Road and Bridge Construction." Backfill will be placed in horizontal layers of 6-inch thickness, maximum, and compacted to a minimum of $92 \%$ of the maximum dry density and within $2 \%$ of the optimum moisture content as determined per AASHTO T-180. The required compaction and moisture content will be verified during fill placement by means of in-place density tests per AASHTO T-191, T-205, or T-238.

Due to its dense and primarily granular nature, the backfill will have a friction angle of at least $40^{\circ}$, with some cohesion (ignored for design), rendering it unsusceptible to liquefaction during an earthquake. Also, while providing excellent compactability during construction, the backfill will minimize lateral pressure on the tank vault walls, compared to a backfill consisting of excavated soil. This assessment concludes that the design and specification of the backfill will ensure that the tank vault structure will be fully and uniformly supported. The installation of the backfill will be inspected to verify conformance with the project specifications. 
- LLW Underground Piping:

Bedding and backfill material immediately surrounding all new pipe will be a uniform mixture of sand and $4 \%$ bentonite. The sand/bentonite mixture will flow freely and compact well during installation, under controlled moisture conditions. These properties facilitate the provision of a uniform bedding and backfill for the buried piping, with desirable physical properties. Due to its swelling capability, the bentonite makes the mixture less permeable to moisture than sand.

The sand will have a maximum moisture content of $10 \%$ just prior to mixing, as determined per AASHTO T-255, and will be a silicious sand produced from crushed sandstone. The maximum levels of leachable chlorides and sulfates will be as follows, as determined by the Government per USDOE's "Determination of Inorganic Anions in Aqueous and Solid Samples by Ion Chromatography" test method:

Sand

Chlorides

Sulfates
$10 \mathrm{ppm}$

$100 \mathrm{ppm}$

\section{Bentonite}

$50 \mathrm{ppm}$

$5000 \mathrm{ppm}$

These limits are established by USDOE to reduce the potential for pipe corrosion. They are based on past experience with other backfills surrounding existing similar piping at the site.

The sand/bentonite mixture will be carefully compacted to $91 \pm 1 \%$ of the maximum dry density, per AASHTO T-180, in layers not exceeding 6 inches in thickness. In-place density and moisture content tests will be performed per AASHTO T-191, T-204, T-205, T-233, or T-238.

This assessment concludes that the design and specification of the backfill will ensure that the buried piping will be fully and uniformly supported. The installation of the backfill will be 
inspected to verify conformance with the project specifications.

\section{IV.B.5. Testing}

The pressure containing boundary of the primary and secondary piping and the LLW and PW tanks is tested for leak tightness prior to being covered, backfilled, enclosed, or placed in service. The leak tests are either pneumatic or hydrostatic tests, conducted in accordance with applicable MMES specifications. These test requirements are noted in the Installation Assessment Summary and are summarized below:

\section{Leak Testing Requirements}

\begin{tabular}{|c|c|c|c|}
\hline System/Component & Type of Test/Media & Code & Spec Reference \\
\hline Primary Pipe & Pneumatic/Nitrogen & B31.3 & 5.410, Table 1 \\
\hline Secondary Pipe & Pneumatic/Nitrogen & B31.3 & 5.410, Table 1 \\
\hline LLW and PW Tanks & Hydrostatic & ASME VIII & 9.101, Para 9.t \\
\hline
\end{tabular}

These reports will be reviewed by the Installation Assessment Team to assure that leak-tight construction has been provided.

\section{IV.B.6. Ancillary Equipment Protection}

The methods implemented to properly support and protect ancillary equipment against physical damage and excessive stress due to settlement, vibration, expansion, or contraction are described herein. The methods used may be divided into three categories as applicable to buried double wall piping systems; single wall piping systems within a lined, seismically designed structure; and the LLW and PW tanks (single wall) within a lined, seismically designed structure.

The buried double wall piping is completely surrounded by a sand-bentonite mixture, with at least 3 feet of cover. The sand-bentonite mixture fills the bottom of the trench in which the piping system is routed. The relatively low moisture permeability of

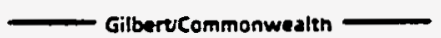


the mixture prevents the sand from acting as a conduit or wick to transport potential leakage significant distances, in the presence of groundwater. The remainder of the trench backfill consists of either a premixed base material of crushed stone or earth.

The buried piping system has been analyzed for the various loading conditions that may apply, including: (1) potential settlement of structures at which the piping system terminates or is anchored; (2) seismic loadings induced by the design basis seismic event; (3) thermal expansion caused by upset operation, with live steam in the primary pipe (potentially caused by operation of a steam jet ejector with suction from a dry tank or sump). The stresses induced in the piping system (primary and secondary pipe) are within ANSI B31.3 code allowable values for the applied loadings.

The single wall LLW piping routed within a lined structure is conservatively supported for dead weight. Where appropriate, additional restraints are provided for lateral forces that may be induced by hydraulic conditions. Seismic restraint is not required since the piping is contained within a lined, seismically qualified structure equipped with a leak detection system. It should be noted that the basic design inherently provides a significant degree of seismic event resistance since most runs of piping in this category are relatively short and stiff. Also, the seismic accelerations are modest because the vault structures are below grade and are themselves relatively rigid. (Amplification of seismic inputs due to structural response is minimal.)

The LLW and PW tanks are welded to support saddles, which in turn, are attached to the floor slab of the underground vault. The tank specification requires that each tank and its supports be designed to withstand specified seismic loadings. The base anchorage and floor slab are designed to withstand uplift and pullout forces caused by seismic loadings.

This assessment concludes that the design has incorporated adequate provisions for the protection of ancillary equipment 
against physical damage and excessive stress. The installation will be assessed in accordance with the requirements presented in the Installation Assessment Summary, Section IV.B.2 of this report.

\section{IV.B.7. Corrosion Protection}

A thorough review of the pertinent drawings and specifications was performed to ensure that all corrosion protection recommendations were incorporated. In addition, all review comments were analyzed to determine if they had been adequately considered. The results of this review found that with the exception of a few minor discrepancies, which have been corrected, all comments and design recommendations have been properly incorporated.

There are a number of procedures that are required to verify whether the cathodic protection system has been properly installed and tested. This is primarily accomplished by measuring pipe to soil potentials. This work is to be performed by a qualified corrosion engineer per N.A.C.E. recommended practice 01-69, Rev. 1983, as noted in Section IV.B-2, Installation Assessment Summary.

This assessment concludes that the design incorporates an appropriate type and degree of corrosion protection for the buried piping. The installation of the corrosion protection system must be supervised by an independent corrosion expert who will, upon completion of the installation, provide a certification that the installation complies with the design requirements. The certification will be audited by the installation inspector as part of the installation assessment.

\section{IV.B.8 Corrosion Expert}

Norton Corrosion Limited, Inc., a firm that specializes in corrosion control, was involved in the design phase of the subject project. This work was assessed by an outside firm hired by Martin Marietta 
that reviewed the design calculations and provided comments. All comments were reviewed and appropriate changes made.

Guidance to ensure the results will be implemented are found in the specifications. These require that the contractor hire a N.A.C.E. certified corrosion engineer to inspect and test the corrosion control system. It also requires submittal of all materials and qualifications for review prior to installation.

\section{IV.B.9 Documentation}

This section contains written statements by those persons required to certify the design of the Tank System and supervise the installation of the Tank System. Separate statements are provided, one covering the design of the Tank System, the other covering the installation of the Tank System. (Exhibits B.9-1 and B.9-2).

The installation certification will be signed and stamped following the completion of the installation and a review of pertinent records documenting required non-destructive examinations, inspections, repairs, and tests. These activities are described in Sections IV.B.2 through and including IV.B.7 of this assessment.

Suitable retrievable permanent records of the results of the aforementioned non-destructive examinations, inspections, repairs, and tests will be maintained by the Information Services Division of Martin Marietta Energy Systems. These records will be reviewed by the person who will, in the future, certify the installation. 


\section{Exhibit B.9-1}

\section{DESIGN CERTIFICATION}

This statement certifies that the Tank System providing Low Level Waste collection, storage, pH adjustment, and transfer for the Transported Waste Receiving Facility (Building 2649) is properly designed, and the design is in accordance with the applicable requirements of 40CFR264, Subpart J - Tank Systems, as set forth in Appendix F to the Federal Facility Agreement, Docket No. 89-04-FF, covering the Oak Ridge Reservation.

This statement applies to the design of the Tank System and to the provisions specified by the design (examinations, inspections, tests) that must be executed during installation, including the conduct of any repairs that may be required during installation. A separate statement must be prepared and certified, following the installation of the Tank System, to attest that the final installation is in compliance with the design and with provisions of 40CFR264, Subpart J - Tank Systems, as presented in Appendix F to the Federal Facility Agreement, Docket No. 89-04-FF.

1, the undersigned, certify that this document was prepared under my direction by qualified personnel who had complete access to pertinent design information. Based on my inquiry of those persons directly responsible for gathering and evaluating the information, the information submitted is, to the best of my knowledge and belief, true, accurate, and complete.
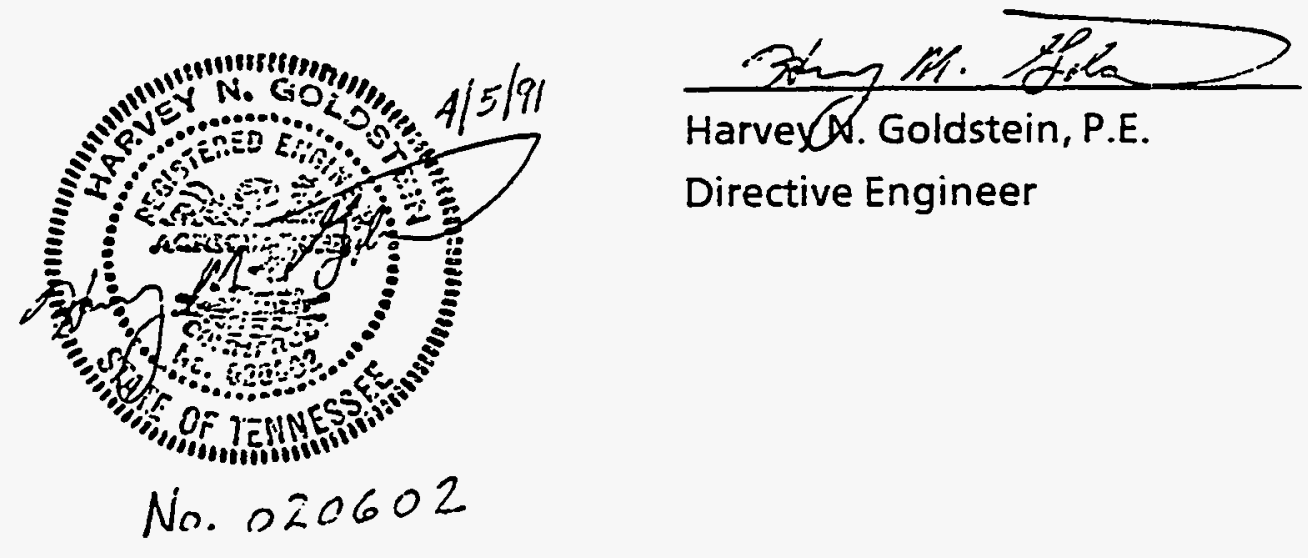

Directive Engineer 
Reserved for Exhibit B.9-2 - Installation Certification

(Please note format used for Design Certification) 


\section{IV.C. Standards for Containment/Release Detection}

The secondary containment systems consist of an outer pipe completely enveloping the primary, inner pipe and lined, seismically designed, reinforced concrete vaults containing the LLW and PW tanks.

The release detection system for the piping system utilizes nitrogen pressure maintained in the annular space between the inner and outer pipes, with continuous pressure monitoring. The release detection system for the tank system utilizes sumps at low points in the liner/vault structure, with level probes set in the sumps to detect the presence of more than a de minimus amount of liquid.

\section{IV.C.1. Secondary Containment Systems Requirements}

(a) Construction Compatibility:

The secondary containment for the piping system is constructed of Type 304L austenitic stainless steel. This material is capable of withstanding exposure to substances that may potentially leak from the service and transfer lines associated with Building 2649. A leak will be detected within a short time interval, which will result in an orderly cessation of waste disposal via the affected service line. The small quantity of liquid leaked from primary to secondary piping will be contained until draining and flushing actions commence.

The secondary containment surface material for all lined vaults and the lined pipe trench which could be exposed to LLW assuming leakage through the primary containment is in all cases Type 304L stainless steel material. The secondary containment is, therefore, compatible with the LLW waste streams or other substances placed in the LLW Tank System. 
The vaults which comprise the MCS part of the TWRF include the following lined areas: tank vaults, valve vault, mist eliminator vaults, and sampler piping chases.

The reinforced concrete vault walls, base slab, and cover slabs have been conservatively designed for appropriate loadings including pressures due to surcharge, seismic, earth, and hydrostatic loadings. For purposes of design, groundwater level was assumed to be at elevation 801 feet, approximately 5 feet below grade level. The assumed level includes a margin of several feet above actual groundwater level. The cover slabs have been designed for a minimum of 300 psf live load and have also been checked for postulated tornado missile loads associated with high hazard classification in accordance with UCRL-15910. The MCS part of the TWRF is basically the same design as the Building 2099 vault structures. The tornado load calculation for Building 2099 included postulated collapse of the adjacent control room and shield walls surrounding the HVAC equipment area, onto the vault roof slab. Other tornado design basis loads that were evaluated include wind pressure, atmosphere pressure change, and missiles, including a wood plank, a steel pipe, and a medium sized automobile. Therefore, the TWRF vault structures which incorporate the same design as the Building 2099 vault structure are also qualified for the above tornado loads.

The relatively thick cover slabs provided for radiation shielding (24 inches over the valve vault , 36 inches over the tank vault) are conservatively adequate for all design loads. The concrete mix design incorporates entrained air to assure durable concrete with no deterioration due to freeze/thaw cycles anticipated over the service life of the vault.

Applicable American Concrete Institute Standards such as $\mathrm{ACl}$ 305, "Hot Weather Concreting," and ACl 306, "Cold Weather 
Concreting," assure the necessary quality of concrete will be achieved under a potential range of climatic conditions during construction. In addition to the many quality requirements embodied in $\mathrm{ACl} 318$ and $\mathrm{ACl} 301$, which are specified, water content and the addition of water to the concrete are carefully controlled to minimize drying shrinkage.

Various in-process tests, including cylinder compressive strength tests, have been required to assure consistency in the concrete mix being furnished.

New LLW pipes within the main TWRF building are located beneath the grade floor level within a stainless steel lined concrete trench and are provided with at least the equivalent of 24 inches of concrete cover for shielding.

\section{(b) Containment Systems Foundation}

The secondary containment system foundation for the vault structures consists of 2 -foot thick reinforced concrete vault base slabs.

The vaults consisting of the LLW and PW tank vault, combined valve vault, and LLW and PW mist eliminator vaults are integrated into a single rigid reinforced concrete structure. This structure is embedded below grade and founded on rock.

Due to the rigid nature of the structure and the foundation bearing on rock, the potential for bearing failure and/or settlement are negligible. The vault structural stability has been checked to assure that the dead weight of the structures conservatively exceeds an assumed buoyancy force due to groundwater level assumed to be at El. $801 \mathrm{ft}$.

The vault base slab has been conservatively designed assuming a rigid slab model for an upward pressure corresponding to the dead plus live load of the superstructure divided by the area of the slab. 
The vault walls have been designed for applicable lateral loads due to surcharge, static earth pressure, hydrostatic head of water, and lateral pressure increment due to a seismic event.

The LLW pipe trench within the main TWRF building consists of a $1 \mathrm{ft}$. thick continuous reinforced concrete base slab founded on $1 \mathrm{ft}$. (minimum) compacted, stabilized aggregate backfill. Eleven inch thick reinforced concrete walls are provided along each side of the $2 \mathrm{ft} .4 \mathrm{in}$. wide lined trench. The walls and base slab are designed for the appropriate lateral and vertical pressure loads.

The stored LLW in the TWRF tanks can be transferred through buried pipes to the $\mathrm{CWCH}$ in existing valve box No. 3 located adjacent to the Evaporator Service Tank Farm (see Exhibit II-1). The inside plan dimension of existing valve box NO. 3 is $4 \mathrm{ft}$. by $8 \mathrm{ft}$. To accommodate the additional piping from the TWRF, value box No. 3 is modified to double the inside plan dimension to $8 \mathrm{ft}$. by $8 \mathrm{ft}$.

Valve box No. 3, which extends about $17 \mathrm{ft}$. below finished grade, is embedded about $5 \mathrm{ft}$. into rock. The existing $2 \mathrm{ft}$. thick base slab is founded on rock and is extended by adding a new $2 \mathrm{ft}$. thick section of foundation mat. The new section is joined to the existing foundation with grouted reinforcing dowels. Since both existing and new sections of the base mat are founded on rock, differential settlement between the existing and new vault sections is precluded.

One wall of the existing box is demolished and new walls are doweled into the existing walls to form the new box. A continuous stainless steel liner is provided on the interior for the first four feet. The valve box has been designed for appropriate lateral soil and hydrostatic pressure loads.

This assessment concludes that the containment systems foundation has the capability to provide support to the 
secondary containment system without failure and is designed for the appropriate loading conditions.

\section{(c) Leak Detection System}

The secondary containment system's leak detection provisions are divided into two approaches:

\section{(i) Double Wall Piping Annulus Leak Detection}

The annular spaces in the double wall piping systems are pressurized with nitrogen. The piping runs are divided in multiple segments, each constituting an independent pressure boundary, by division plates in the piping system.

The system configuration, for the buried double wall transfer lines conveying LLW from Building 2649 to valve box No. 3, divides the pipe into segments with a test and monitoring station provided at the junction between segments. Pressure monitoring for each line utilizes two pressure switches (1 out of 2 logic) serving all the buried pipe segments. If a potential leak is detected, by decrease of annular space pressure, the leak location may be determined by acoustic monitoring or by entering the test and monitoring station and sequentially isolating segments of the buried line.

The assessment concludes that the aforementioned leak detection system for the annular space of the double wall piping system is capable of detecting virtually all leaks within considerably less than 24 hours.

\section{(ii) Vault/Pipe Trench Leak Detection System}

The detection of leaks from the tanks or piping into any of the vaults or the pipe trench beneath the floor in the TWRF is based on the provision of sumps at the low 
points in the sloping floors.

Any leakage from either tank or single wall piping would flow by gravity to a sump, which is provided with a conductivity type level detection device. The time period required for this accumulation of liquid will vary inversely with the rate of a potential leak (i.e., the larger the leak, the shorter will be the time interval required to detect the leak).

The total quantity of a non-detected leak represents a very small fraction of the minimum rated tank capacity ( 1100 gallons), and is contained by the sump liner, which is a continuous part of the vault liner. The assessment concludes, therefore, that extremely small leaks, even if not detected within 24 hours, will be detected at the earliest practical time.

\section{(d) Drainage and Liquid Removal}

The secondary containment systems are designed to permit removal of accumulated liquids arising from leaks, spills, or condensation within the secondary containment volumetric envelope.

\section{(i) Double Wall Piping Annulus Liquid Removal}

The double wall piping is sloped to a low point at both of its ends. A drain nipple is provided at a localized low point near the center of the pipe run, with connecting tubing routed to a connecting point from which accumulations of liquids arising from potential leaks may be removed. The annular space drain points are accessible from a test and monitoring station provided at the pipeline segment junction. Leaked substances may be removed in the length of time required to detect a leak and gain access to the test and monitoring station, 
which consists of a standard concrete pipe section installed vertically with a weatherproof cover.

Additional connections are provided to the annular space for venting and/or injection of a flushing liquid, if required.

The as-built plan and profile of the buried piping will be reviewed during the installation assessment to assure that the design provisions for liquid removal capability are not compromised. Deviations in plan and profile during construction of the buried pipe lines must have engineering approval prior to final placement of the piping.

\section{(ii) LLW Tank Liquid Removal}

The tank vaults containing the $L L W$ and $P W$ tanks are each provided with a sloped floor and a sump of approximately 14 gallons net capacity. Each sump is provided with two steam jet ejectors that can pump any accumulated liquid back to the LLW tank or to the LLW transfer line for conveyance to the $\mathrm{CWCH}$ at valve box No. 3. The steam jet ejectors can operate to remove liquids within minutes of a decision to do so.

\section{(iii) Single Wall Piping Liquid Removal}

The single wall LLW piping within the confines of the TWRF's MCS valve and tank vaults, the pipe trench, and valve box No. 3 are provided with secondary containment by the stainless steel liners. Leaking liquids are captured by the sumps provided and removed by means of steam jet ejectors. The valve vault is provided with a single steam jet ejector, which is piped to convey any accumulated liquid from the valve vault sump to the LLW tank. Each tank vault sump is provided with two

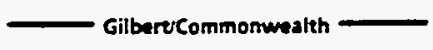


ejectors, as discussed in (d)(ii) above. The sump within the main TWRF building pipe trench as well as the sump in valve box No. 3 will require removal of liquids by portable means.

This design assessment discovered that the covered pipe trench in the TWRF floor was not provided with a means for removal of accumulated liquids. A design change will be undertaken to incorporate an access port above the trench low point.

\section{(e) Secondary Containment for Tanks}

The secondary containment system for the LLW and PW tanks consists of a stainless steel liner external to the tank. The liner is continuously welded so that it forms a leak-tight containment system for liquids. The liner is attached to the inner surface of a reinforced concrete vault. The vault structure is designed to withstand specific, defined loading conditions, as described in paragraph IV.B.1.(e) of this assessment.

The Building 2649 LLW and PW tanks, therefore, are provided with two specific features, integrated into a secondary containment system, which provide a high degree of environmental protection against leaks or spills from the tanks.

\section{(f) Additional Requirements}

\section{(i) External Liner Systems}

The design of this Tank System does not utilize an external liner to achieve compliance with 40CFR264 Subpart I requirements. However, an external waterproofing membrane is provided on the outside of the vault structures described below. The function of this membrane is discussed in (ii)(d). 
(ii) Vault Systems

\section{(A) Capacity}

The Building 2649 tank vaults are each provided with a leak-tight stainless steel liner, from and including the floor of the vault, up to a height of 4 ft. -6 in. (nominal) above the floor. This provides a gross volume of approximately 7,500 gallons, compared to the tank volume, at overflow, of approximately 2,000 gallons. The lined vault system, therefore, provides a margin of safety in capacity of several times the volume of the LLW or PW tank contained within its respective vault.

\section{(B) Run-on or Infiltration Prevention}

Surface water drainage is directed around the TWRF tank vaults by means of site grading. Site grades immediately surrounding the TWRF tank vaults slope away from the building and direct runoff to swales conveying the water to a disposal point. In addition, site grades are maintained at lower elevations than the vault perimeter walls. Storm drain catch basin inlets, as well as existing site topographic relief, prevent the build-up of surface water during storm/rainfall events.

The design of the surface water drainage is combined with the characteristics of the vault subsurface design to prevent surface run-off from entering the vault. The presence of existing site fine-grained soils, combined with the dense tank vault backfill materials and the proposed adjacent asphalt paving and concrete sidewalk, will minimize surface water infiltration as a result of precipitation. The reinforced concrete tank vault 
walls and the external waterproofing membrane also will prevent run-on or infiltration effects.

The vault system has been provided with redundant design features to prevent run-on or infiltration of precipitation into the secondary containment system. The cover slabs are provided with drainage pitch to channel water off the top surface of the vault and into the surface run-off drainage system. The opening into each tank vault for installation (or removal) of the tank is provided with a two-piece cover slab arrangement that provides redundancy against infiltration at the openings. Each of the two pieces completely covers the opening in the stacked arrangement. Each slab is also furnished with a continuous flexible gasket under the perimeter that is compressed to provide a seal. The top cover slab extends horizontally over a continuous curb provided around the perimeter of the opening. This cover slab arrangement provides redundancy against infiltration and also eliminates flexible seals in a potential direct leakage path into the vault through use of the concrete curb.

The secondary containment design feature for valve box No. 3 is also considered to be a vault system. Similar provisions to prevent run-on or infiltration as described above for the tank vaults were applied to valve box No. 3 , including proper surface drainage slope away from the valve box, a gasketed one-piece cover slab with pitched top surface, and waterproofing membrane below grade.

The pipe trench within the main TWRF building is protected from infiltration due to precipitation by 
virtue of its location within an enclosed building. It is also protected against any run-on or infiltration of liquid from any source within the building by the reinforced concrete floor slab which covers the trench and is pitched to a floor drain. Ground water infiltration into the trench is precluded by the following provisions: the exterior of the trench walls is provided with portland cement plaster plus asphaltic surface coating; waterstops are provided; the stainless steel liner covering the bottom and sides of the trench extend above groundwater. The liner is anchored at relatively close spacing and can withstand groundwater pressure without permitting any water into the trench.

The reinforced concrete vault structures meet applicable requirements of $A C I 350 R$ for concrete sanitary engineering structures, including reinforcing ratios and bar spacing as well as concrete quality.

\section{(1) Water Stops}

Six-inch flexible polyvinyl chloride waterstops are typically provided in construction joints below grade. This material is chemically resistant.

In several joints, such as where the new walls and foundation slab for the valve box No. 3 modification are placed against the existing walls and slab, the waterstop material is a hydrophylic chloroprene expansion rubber that swells upon contact with water. 


\section{(2) Coating or Lining}

The interior of the concrete vaults, pipe trench, and valve box No. 3 is provided with an impermeable coating and lining that is compatible with the stored waste and will prevent the migration of waste into the concrete. A continuous stainless steel liner is fastened to the interior surface of the vault base slab and walls. This liner provides the leak-tight barrier to contain more than $100 \%$ of the tank volume (see Paragraph IV.C.1.(f)(ii)(A). The remainder of the interior surfaces of the tank vaults above the stainless steel liners are coated with an impermeable epoxy coating system that will prevent migration of any liquid through it into the concrete.

\section{(C) Vapor Protection}

The vault systems are provided with the means to protect against the formation and ignition of vapors within the LLW or PW tank and within the valve and tank vaults. These provisions are comprised of multiple design features, as described below.

The LLW and PW tanks are the only potential sources of ignitable waste since wastes are normally contained only in the tanks and not in the vaults. Ignitable waste may evolve in the LLW or PW tank in the form of the gaseous phase of any of several organic liquids such as acetone, benzene, methanol, or ethanol. These liquids may be used, in small quantities, in the operations of Building 
2649 and, hence, may be discharged to the LLW or PW tank.

A study by ORNL personnel (Ref. Appendix $G$ of the System Requirements Document for the Bethel Valley LLW Project) examined the potential for ignitable vapor formation within a typical waste tank, and evaluated ventilation rates that would maintain concentrations of the ignitable vapors below the flammability limit.

The principal means of protection against the formation and ignition of vapors within the LLW tank is the provision of direct ventilation of the gas space above the liquid level in the tank. The ventilation rate is set at $100 \mathrm{cfm}$, which is well in excess of flow rates established in Appendix $G$ of the Bethel Valley LLW System Requirements Document.

The ventilation rates for the valve and tank vaults are set at $240 \mathrm{cfm}$ by space heating and normal ventilation criteria. Since no identified mechanism exists for vapor formation in the vaults, the aforementioned ventilation rate should be more than adequate to maintain the vaults free of any potential for vapor formation and ignition.

A second design provision that provides detection of vapors is the combustible gas detection instrumentation. A combustible gas monitor sensor is located in the ventilation air exhaust from the LLW and the PW storage tank, downstream of each mist eliminator. This sensor is flange mounted into the exhaust duct to allow ease of removal for calibration. The sensor is a catalytic bead diffusion type operating on 24 VDC supplied by readout 
module in the control room panel. The readout provides a display range of $0.99 \%$ Lower Explosive Limit with an alarm output set at $50 \%$ or less to the Local Control Unit (LCU). Alarm is also provided on loss of power, or unit malfunction.

A third design provision that provides protection against the formation and ignition of vapors is a nitrogen flooding system that enables the operator to purge the vapor space of the LLW tank and establish a nitrogen blanket above the liquid in the tank. The ventilation to the tank would be terminated prior to establishing the nitrogen blanket, which can be maintained until operational decisions are made for handling the situation.

Another design feature that assists in the protection against the ignition of vapors within the tank includes the specification of an explosion-proof type duct heater in the duct exhausting from the LLW tank, through the mist eliminator, and to the first exhaust HEPA filter. A duct heater is required to reduce the relative humidity of the air stream to the HEPA filter; the explosion-proof rating reduces or eliminates the potential for ignition of any flammable vapors that may be present.

Finally, the LLW tank is grounded, minimizing the potential for the bulld-up of a static charge, with subsequent discharge of a spark or are which could ignite any flammable vapors that may be present.

\section{(D) Moisture Migration}

The reinforced concrete vault structure has been conservatively designed for hydraulic pressure from 
groundwater level assumed to be approximately 5 feet below grade. While groundwater levels are normally well below that level, an impervious, continuous, single layer elastomeric waterproofing membrane has been provided.

The waterproofing membrane completely envelopes the exterior surfaces of the vault, including under the base slab and along the walls up to a level approximately 6 inches below finished grade. Finished grade around the vault is sloped to channel surface run-off away from the vault. The surrounding area consists of asphalt paving and concrete sidewalk thereby minimizing the potential for runoff infiltration.

It is concluded that the provision of the external membrane waterproofing system will prevent migration of moisture into the vaults.

(iii) Double Walled Tanks - Not Applicable

\section{(iv) Support Equipment}

Support equipment is provided with secondary containment that meets the requirements stated previously in this section (IV.C.) except for limited portions of aboveground piping that are visible for inspection on a daily basis. These piping segments are located in specific areas within Building 2649, principally in the Truck Unloading Zone and Bottle Storage Room. Other items of ancillary equipment and their secondary containment features are noted below.

- Buried or embedded piping is provided with double wall construction, the outer pipe constituting the secondary boundary. Leak detection and a means of removal of accumulated leakage are provided 
for the annular spaces between the primary and secondary pipes.

- Steam jet ejectors, used to pump liquid waste from the LLW and PW tank and vault sumps, are housed below grade within the lined secondary containment vaults.

- Portions of the LLW and PW tank ventilation equipment that may contain liquid waste (principally the mist eliminators and associated piping) are located within lined vaults, adjacent to and structurally integral with the tank vaults. The floor of each mist eliminator vault is equipped with a floor drain that is piped to the respective waste tank. The embedded portion of the mist eliminator vault floor drain piping is provided with an outer, secondary pipe.

This outer pipe is seal welded to the mist eliminator vault floor liner, but is open as it enters the respective tank vault. Potential leakage from the inner pipe would be contained by the outer pipe and would flow by gravity to the tank vault sump where it would be detected by the sump level detection instruments.

It should be noted, however, that if the mist eliminator vessel, or its connecting pipe or flanges were to leak, this leak could not be directly detected. Any leakage would be conveyed to the respective waste tank via the mist eliminator vault floor drain. The leakage could not accumulate, but instead is directly returned to the primary containment vessel from which it originated. This condition was observed during the assessment review process; a design change to reroute each 
mist eliminator vault floor drain to its respective tank vault sump will be implemented. This will provide the capability to detect potential leaks from a mist eliminator vessel and its connecting piping and flanges.

- The HEPA filter housings, comprising part of the tank ventilation system, are located above grade and are accessible for daily inspection. The housings are equipped with valved closed drain connections, which may be manually drained on a periodic basis.

- Flanged connections used for tie-ins of the transfer line to the $\mathrm{CWCH}$ are located in modified existing value box No. 3. The value box is provided with a stainless steel liner and a sump (the liner is continuous and includes the sump), and an access port in the box cover slab. The access port permits sampling and removal of accumulated liquids. A leak detection system has not been provided for valve box No. 3 as part of the scope of work for the Bethel Valley LLW Upgrade, which was limited to new valve boxes only.

The Bethel Valley LLW Upgrade scope at existing valve boxes only included modifications to the piping and box structure to permit tie-in to the $\mathrm{CWCH}$. The provision of a leak detection system for existing valve boxes should be considered in future LLW upgrades.

- The design of this facility does not employ sealless or magnetic coupling pumps and sealless valves that require inspection on a daily basis. 
- The design of this facility does not employ pressurized aboveground piping systems with automatic shut-off devices for the liquid waste.

In summary, this assessment concludes that ancillary equipment is provided with acceptable secondary containment provisions, including leak detection and means for removal of accumulated liquids, as applicable. 


\section{v. CONCLUSION}

This assessment concludes that the completed design for the new Tank System for Building 2649 meets the applicable requirements of 40CFR 264 Subpart $J$-Tank Systems, as presented in Appendix F to the Federal Facility Agreement, Docket No. 89-04-FF.

- The waste tank and primary (inner) piping are specified to the appropriate codes and with the appropriate materials to provide satisfactory longevity in the intended service. The specifications require appropriate materials properties, weld examination and inspection, testing, and final visual inspections to assure leak tight integrity.

- Secondary containment features are provided where required for the waste tanks and buried or embedded piping. Leak detection and means of removing accumulated liquids are provided in the design. The vault structures have been designed for the applicable loadings and load combinations for high hazard category structures, in accordance with UCRL 15910, including loadings associated with postulated seismic and tornado occurrences. A stainless steel liner has been provided in the vaults as the secondary containment barrier. Appropriate materials, fabrication and installation techniques, examinations and inspections have been specified to assure that the required quality and integrity of the design is achieved during construction.

- The buried piping is provided with a corrosion control system that projects a useful life span well in excess of the planned operational life of the system ( 162 years versus 25 years). Overall the corrosion control designs offer a very conservative approach and meet all criteria listed. The main concern with any cathodic protection system, but especially a galvanic system, is to maintain electrical isolation from all foreign structures. This has been accomplished throughout the design phase and is incorporated in the testing procedures to assure that isolation is maintained following installation.

- The civil and geotechnical engineering design provides a satisfactory approach to the overall integrity of the Tank System and is based upon 
site, subsurface, and pipe backfill data provided by the Government to the Architect/Engineer. Project construction drawings and technical specifications provide requirements, tests, and approvals necessary to assure a successful installation.

- Support equipment is protected against physical damage and excessive stress due to vibration, settlement, and expansion or contraction.

Secondary containment is provided for ancillary equipment, meeting the same standards as for the waste tank. Two exceptions were noted during the assessment review (the mist eliminator vault drains, Section IV.C. 1.(f) (iv)), and provision of a means for removal of accumulated liquids from the pipe trench below the TWRF floor, Section IV.C.1.(d)(iii). Minor design changes will be implemented to provide complete conformance to leak detection and liquid removal requirements. In addition, it is noted that provision of leak detection for existing valve box No. 3 was not within the scope of work for the Bethel Valley LLW Upgrade. Future upgrades should consider provision of leak detection for this and other valve boxes, as may be required.

- The installation assessment, to be performed during installation and prior to commissioning of the system, is to confirm that design provisions have been correctly implemented. The Installation Assessment Team will review pertinent test and inspection records, and perform visual inspections, walkdowns, and witness functional tests to achieve this objective. An installation certification is to be prepared and inserted in Section IV.B.9 of this document. 
Appendix A

Drawing List of Transported Waste Receiving Facility-Building 2649 
Drawing

Number

$\begin{array}{ll}\text { A3E-21354-BO11 } & 0 \\ \text { A3E-21254-BO12 } & 0 \\ \text { A3E-21254-BO13 } & 0 \\ \text { A3E-21254-BO14 } & 0 \\ \text { A3E-21354-BO15 } & 0 \\ \text { A3E-21354-BO16 } & 0 \\ \text { A3E-21354-BO17 } & 0 \\ \text { A3E-21354-BO18 } & 0 \\ \text { A3E-21354-BO19 } & 0 \\ \text { A3E-21354-BO20 } & 0 \\ \text { A3E-21354-BO21 } & 0 \\ \text { A3E-21354-BO23 } & 1 \\ \text { A3E-21354-BO24 } & 0 \\ \text { A3E-21354-BO25 } & 0 \\ \text { A3E-21354-B026 } & 0 \\ \text { A3E-21354-BO27 } & 0 \\ \text { A3E-21354-BO37 } & 0 \\ \text { A3E-21354-BO38 } & 0\end{array}$

C3E-20013-A000

C3E-21354-A002

C3E-21354-A003

C3E-21354-A004

C3E-21354-A005

C3E-21354-A006

C3E-21354-A007

C3E-21354-A008

C3E-21354-A009

C3E-21354-A010

E3E-20013-D044

E3E-21354-D001

E3E-21354-D002

E3E-21354-D003

E3E-21354-D004

E3E-21354-D005

E3E-21354-D006

E3E-21354-D007

E3E-21354-D008

E3E-21354-D009

E3E-21354-D010

E3E-21354-D011

E3E-21354-D012

E3E-21354-D013

E3E-21354-D023
Revision

0

0

0

0

0
0
0
0
0
0
0
0
0
0

1

0

0

0

0

1

0

0

0

1
Title

Architectural

Architectural - Plan at Grade

Architectural - Auxiliary Plan Above Grade

Architectural - Roof Plan

Architectural - Sections \& Interior Elevation Ref.

Architectural - North \& South Elevations

Architectural - East \& West Elevations

Architectural - Longitudinal Section 1-1

Architectural - Longitudinal Section 2-2 \& Details

Architectural - Rear Elevations, Sections \& Details

Architectural - Sections \& Details

Architectural - Interior Elevations

Architectural - References \& Schedules

Bldg. \& Equipment Arrangement - Floor Plan El. 805'-O'

Bldg. \& Equipment Arrangement - Plan Below El. 805'-O'

Bldg. \& Equipment Arrangement - Roof Plan

Bldg. \& Equipment Arrangement - Sections A-A \& B-B

Architectural - Through Roof \& Wall Penetration Details

Architectural - Sections and Details

\section{Civil}

External Piping for TWRF - Drawing Index - Cover Sheet 1 of 1

Locality Map

Construction and Operation Areas

Civil Details, Legend, and General Notes

Site Demolition Plan

Site Plan and Section

Yard Piping Plan and Profile

Drawing Index - Cover Sheet 1 of 3

Drawing Index - Cover Sheet 2 of 3

Drawing Index - Cover Sheet 3 of 3

Electrical

External Piping for TWRF - Electrical - Cathodic Protection Layout Plan, Transfer Line Piping

Electrical - One Line Diagram 32-3B 480V Motor Control Center

Electrical - Panel Schedule \& Details 480V Front View \& Panel Diagrams

Electrical - Elementary Diagram HVAC Systems

Electrical - Elementary Diagram HVAC Systems

Electrical - Elementary \& Wiring Diagrams Heat Trace, HVAC \& Misc.

Systems

Electrical - Conduit Layout Plan at Grade

Electrical - Conduit Layout Plans \& Details Below Grade \& Roof

Electrical - Cable Tray Layout Plan, Sections \& Details

Electrical - Lighting Layout Details \& Schedule

Electrical - Lighting Layout Plan

Electrical - Lighting Layout Receptacle Plan

Electrical - Grounding Layout Plan, Notes \& Legend

Electrical - Grounding Layout Plan, Sections \& Details

Electrical - Conduit Layout, Plan, Sections \& Details - Overhead

Lines 
Drawing Number

E3E-21354-D024

E3E-21354-D025

E3E-21354-D026

E3E-21354-D027

E3E-21354-D028

E3E-21354-D029

E3E-21354-D030

E3E-21354-D031

E3E-21354-D032

E3E-21354-D033

E3E-21354-D034

H3E-21354-G001

H3E-21354-G002

H3E-21354-G003

H3E-21354-G004

H3E-21354-G005

H3E-21354-G006

H3E-21354-G007

H3E-21354-G008

H3E-21354-G009

H3E-21354-G010

H3E-21354-G011

H3E-21354-G012

H3E-21354-G013

H3E-21354-G014

H3E-21354-G015

H3E-21354-G016

H3E-21354-G017

H3E-21354-G018

I3B-21354-0001

I3B-21354-0002

I3B-21354-0003

I3B-21354-0004

I3B-21354-0005

I3B-21354-0006

I3B-21354-0007

I3B-21354-0008

I3B-21354-0009

I3B-21354-0010

[3B-21354-0011

I3B-21354-0012

I3B-21354-0013

I3B-21354-0014

I3B-21354-0015

I3B-21354-0016 $\underline{\text { Revision }}$

0
0
0
0
0
0
0
0
1
1
0

0

0

0
Title

Electrical

Electrical - Cable List

Electrical - Cable List

Electrical - Cable List

Electrical - Cable List

Electrical - Cable List

Electrical - Cable List

BVLLW Central Instrm. Fiber Optic Cable Loops "A" and "B" CND

Electrical - Fire Protection Layout, Plan at Grade

Electrical - Wiring Diagram, Fire Alarm System

Electrical - Cable List

Environmental Control (HVAC)

Building Services - HVAC Fluid System Diagram Above Grade Facilities

Building Services - HVAC Fluid System Diagram Tank Area

Building Services - HVAC Plan at Grade

Building Services - HVAC Plan Below Grade

Building Services - HVAC Roof Plan and Details

Building Services - HVAC Section A-A

Building Services - HVAC Section B-B

Building Services - HVAC Section C-C

Building Services - HVAC Section D-D

Building Services - HVAC Section E-E and H-H

Building Services - HVAC Section F-F, G-G and I-I

Building Services - HVAC Elevation 1-1

Building Services - HVAC Details

Building Services - Control Diagram, HVAC - Sheet 1

Building Services - Control Diagram, HVAC - Sheet 2

Building Services - Control Diagram, HVAC - Sheet 3

Building Services - Control Diagram, HVAC - Sheet 4

\section{Instrumentation}

Process Instrument Tabulation, Sheets 1-9

HVAC Instrument Tabulation, Sheets 1-7

Loop Diagram - PW Tank Pressure PDT-4901

Loop Diagram - PW Tank Temperature TE-4902

Loop Diagram - PW Tank Temperature TE-4903

Loop Diagram - PW Tank Level LT-4904

Loop Diagram - PW Tank Level LT-4905

Loop Diagram - PW Tank Level LT-4906

Loop Diagram - PW Tank PH AE-4907

Loop Diagram - Sump Levels LE-4908, 4925, 4933

Loop Diagram - Pipe Trench Sump LVL LE-4938

Loop Diagram - Bottle Storage Room Press. PDT-4939

Loop Diagram - PW Tank Vault Pressure PDT-4911

Loop Diagram - LLW Tank Pressure PDT-4912

Loop Diagram - LLW Tank Temperature TE-4913

Loop Diagram - LLW Tank Temperature TE-4914 
TRANSPORTED WASTE RECEIVING FACILITY - BUILDING 2649 (continued)

Drawing

Number

13B-21354-0017

13B-21354-0018

I3B-21354-0019

I3B-21354-0020

I3B-21354-0021

I3B-21354-0022

I3B-21354-0023

I3B-21354-0024

13B-21354-0025

13B-21354-0026

13B-21354-0027

I3B-21354-0028

I3B-21354-0029

I3B-21354-0030

I3B-21354-0031

I3B-21354-0032

I3B-21354-0033

I3B-21354-0034

I3B-21354-0035

I3B-21354-0036

I3B-21354-0037

I3B-21354-0038

I3B-21354-0039

I3B-21354-0040

I3B-21354-0041

I3B-21354-0042

I3B-21354-0043

I3B-21354-0044

I3B-21354-0045

I3B-21354-0046

I3B-21354-0047

I3B-21354-0048

I3B-21354-0049

I3B-21354-0050

I3B-21354-005]

I3B-21354-0052

I3B-21354-0053

I3B-21354-0054

I3B-21354-0055

I3B-21354-0056

I3B-21354-0057

I3B-21354-0058

I3B-21354-0059

I3B-21354-0060

I3B-21354-0061

I3B-21354-0062

I3B-21354-0063

I3B-21354-0064

I3B-21354-0065 $\underline{\text { Revision }}$

A

A

A

A

A

A

A

A

A

A

A

A

A

A

A

A

A

A

A

A

A

A

A

A

A

A

A

A

A

A

A

A

A

A

A

A

A

A

A

A

A

A

A

A

A

A

A

A

A
Title

Instrumentation

Loop Diagram - LLW Tank Level LT-4915

Loop Diagram - LLW Tank Level LT-4916

Loop Diagram - LLW Tank Level LT-4917

Loop Diagram - Truck Unloading Room Pressure, PDT-4942

Loop Diagram - LLW Tank Sump Level LE-4919

Loop Diagram - LLW Tank PH AE-4918

Loop Diagram - LLW Annulus Dischange Press. PT-4921

Loop Diagram - LLW Tank Vault Press. PDT-4922

Loop Diagram - Caustic Addition Tank Temperature TE-4923

Loop Diagram - Caustic Addition Tank Level LT-4924

Loop Diagram - Tank Truck Level LT-4920

Loop Diagram - Truck Unloading Exhaust Fan Inlet Press. PDT-4940

Loop Diagram - Truck Unloading Exhaust Air Flow FE-4941

Loop Diagram - Bottle Storage RM Exhaust Air Flow FE-4943

Loop Diagram - LLW Mist Eliminator PDT-4946

Loop Diagram - PW Mist Eliminator PDT-4947

Loop Diagram - Filter Plenum-7B Total Pressure Drop PDT-4949

Loop Diagram - Bottle Enclosure 1 Pressure Control PDT-4965A

Loop Diagram - Bottle Enclosure 2 Pressure Control PDT-4965B

Loop Diagram - Filter Plenum-4 Total Pressure Drop PDT-4966

Loop Diagram - Filter Plenum-5 Total Pressure Drop PDT 4967

Loop Diagram - Filter Plenum-3 Total Pressure Drop PDT-4969

Loop Diagram - Filter Plenum-2 Total Pressure Drop PDT-4970

Loop Diagram - Filter Plenum-1 Total Pressure Drop PDT-4971

Loop Diagram - Filter Plenum-6B Total Pressure Drop PDT-4973

Loop Diagram - Filter Plenum-10B Total Pressure Drop PDT-4974

Loop Diagram - PW Tank Vault Bypass Air Flow FE-4975

Loop Diagram - PW Mist Eliminator Air Flow FE-4976

Loop Diagram - Filter Plenum-9B Total Pressure Drop PDT-4977

Loop Diagram - Filter Plenum-11B Total Pressure Drop PDT-4979

Loop Diagram - PW Valve Pit Return Air Flow FE-4980

Loop Diagram - PW Tank Vault Retum Air Flow FE-4981

Loop Diagram - PW Combustible Gas AE-4982

Loop Diagram - Filter Plenum-12B Total Pressure Drop PDT-4983

Loop Diagram - Filter Plenum-7A Total Pressure Drop PDT-4985

Loop Diagram - Filter Plenum-6A Total Pressure Drop PDT-4986

Loop Diagram - Filter Plenum-10A Total Pressure Drop PDT-4987

Loop Diagram - LLW Tank Vault Bypass Air Flow FE-4988

Loop Diagram - LLW Mist Eliminator Air Flow FE-4989.

Loop Diagram - Filter Plenum-9A Total Press. Drop PDT-4990

Loop Diagram - Filter Plenum-11A Total Press. Drop PDT-4992

Loop Diagram - LLW Valve Pit Retum Air Flow FE-4993

Loop Diagram - LLW Tank Vault Return Air Flow FE-4994

Loop Diagram - LLW Combustible Gas AE-4995

Loop Diagram - Filter Plenum-12A Total Pressure Drop PDT-4996

Loop Diagram - EF-4A \& B Exhaust Fans Inlet Press. PDT-4997

Loop Diagram - Demineralized Water Tank Level LT-4952

Loop Diagram - Caustic Tank Hi-Level LE-4923

Loop Diagram - Bottle Storage Room Fan Inlet Press. PDT-4978 
Drawing

Number

I3B-21354-0066

I3B-21354-0067

I3B-21354-0068

I3B-21354-0069

I3B-21354-0070

I3B-21354-0071

I3B-21354-0072

I3B-21354-0073

I3B-21354-0074

I3B-21354-0075

I3B-21354-0076

I3B-21354-0077

I3B-21354-0078

I3B-21354-0079

I3B-21354-0080

[3B-21354-0081

13B-21354-0082

I3B-21354-0083

I3B-21354-0084

I3B-21354-0085

I3B-21354-0086

I3B-21354-0087

I3B-21354-0088

I3B-21354-0089

I3B-21354-0090

I3B-21354-0091

I3B-21354-0092

I3B-21354-0093

I3B-21354-0094

13B-21354-0095

I3B-21354-0096

I3B-21354-0097

I3B-21354-0098

I3B-21354-0099

I3B-21354-0100

I3B-21354-0101

I3B-21354-0102

I3B-21354-0103

I3B-21354-0104

I3B-21354-0105

I3B-21354-0106

I3B-21354-0107

I3B-21354-0108

[3B-21354-0109

I3B-21354-0110

I3B-21354-0111

I3B-21354-0112

I3B-21 354-0113
Revision

A

A

A

A

A

A

A

A

A

A

A

A

A

A

A

A

A

A

A

A

A

A

A

A

A

A

A

A

A

A

A

A

A

A

A
A
A
A
A
A
A
A
A
A
A
A
A

Title

Loop Diagram - Filter Plenum-14 HEPA Press. Drop, PDT-4945

Loop Diagram - LLW Annulus Discharge Pressure PSL-4921A

Loop Diagram - Steam Water \& Air Pressure PT-4929, 4932, 4934

Loop Diagram - PW Tank Disch Header Line Temp. TE-4909A

Loop Diagram - PW Tank Vault Sump to Tank Disch. Temp. TE-4909B

Loop Diagram - PW Tank - LLW Tank Transfer HDR Line -Temp. TE-4909C

Loop Diagram - LLW Tank Discharge Header Line Temp. TE-4910A

Loop Diagram - LLW Tank Vault Sump to Tank Disch. Temp. TE-4910B

Loop Diagram - Valve Pit Sump Discharge Temperature TE-4910C

Loop Diagram - Truck Disch to LLW Tank Line Temp. TE-4910D

Loop Diagram - Filter Plenum-18 Total Pressure Drop PDT-4962

Loop Diagram - Filter Plenum-15 Total Pressure Drop PDT-4963

Loop Diagram - Filter Plenum-16 Total Pressure Drop PDT-4964

Loop Diagram - Air Press. Alarm PSL-4934

Loop Diagram - Jet Discharge Valve ROV-4903

Loop Diagram - Jet Discharge Valve ROV-4904

Loop Diagram - PW Outlet Valve ROV-4908

Loop Diagram - Jet Discharge Valve ROV-4909

Loop Diagram - Fl. Drain Valve ROV-4932

Loop Diagram - Caustic VAlve ROV-4933

Loop Diagram - F-1702 Sparger Valve ROV-4919

Loop Diagram - Jet Valve ROV-4926

Loop Diagram - Valve ROV-4956

Loop Diagram - Jet Valve ROV -4927

Loop Diagram - Jet Valve ROV-4928

Loop Diagram - Jet Valve ROV-4029

Loop Diagram - PW Inlet Valve ROV-4935

Loop Diagram - Jet Dis. Valve ROV-4938

Loop Diagram - Jet Dis. Valve ROV-4941

Loop Diagram - Jet Dis. Valve ROV-4931

Loop Diagram - Caustic Pump

Loop Diagram - Air Press. Alarm PSL-4935

Loop Diagram - LLW Inlet Valve ROV-4911

Loop Diagram - Jet Dis. Valve ROV-4912

Instrumentation

Loop Diagram - Jet Dis. Valve ROV-4913

Loop Diagram - Jet Dis. Valve ROV-4914

Loop Diagram - LLW Hdr. Valve ROV-4915

Loop Diagram - LLW Hdr. Valve ROV-4916

Loop Diagram - Bot. Waste Valve ROV-4917

Loop Diagram - LLW Caustic Valve ROV-4934

Loop Diagram - Jet Dis. Valve ROV-4954

Loop Diagram - Sparger Valve ROV -4918

Loop Diagram - Jet Valve ROV -4920

Loop Diagram - Jet Valve ROV -4921

Loop Diagram - Jet Valve ROV -4922

Loop Diagram - Jet Valve ROV-4923

Loop Diagram - Jet Valve ROV-4924

Loop Diagram - Jet Valve ROV-4925 
TRANSPORTED WASTE RECEIVING FACILITY - BUILDING 2649 (continued)

\begin{tabular}{|c|c|}
\hline $\begin{array}{l}\text { Drawing } \\
\text { Number }\end{array}$ & Revision \\
\hline$\overline{13 B-21354}-0114$ & $\bar{A}$ \\
\hline 13B-21354-0115 & A \\
\hline I3B-21354-0116 & A \\
\hline I3B-21354-0117 & A \\
\hline I3B-21354-0118 & A \\
\hline 13B-21354-0119 & A \\
\hline I3B-21354-0120 & A \\
\hline 13B-21354-0121 & A \\
\hline I3B-21354-0122 & A \\
\hline I3B-21354-0123 & A \\
\hline I3B-21354-0124 & A \\
\hline I3B-21354-0125 & A \\
\hline I3B-21354-0126 & A \\
\hline I3B-21354-0127 & A \\
\hline I3B-021354-0135 & 0 \\
\hline I3B-021354-0136 & 0 \\
\hline I3B-021354-0137 & 0 \\
\hline I3B-021354-0138 & 0 \\
\hline I3B-021354-0139 & 0 \\
\hline I3B-021354-0140 & 0 \\
\hline I3B-021354-0141 & 0 \\
\hline I3B-021354-0142 & 0 \\
\hline I3B-021354-0143 & 0 \\
\hline I3E-21354-0001 & 0 \\
\hline I3E-21354-0002 & 0 \\
\hline I3E-21354-0003 & 1 \\
\hline I3E-21354-0004 & 0 \\
\hline I3E-21354-0005 & 1 \\
\hline I3E-21354-0006 & 0 \\
\hline I3E-21354-0007 & 0 \\
\hline I3E-21354-0008 & 0 \\
\hline I3E-21354-0009 & 0 \\
\hline I3E-21354-0010 & 0 \\
\hline I3E-21354-0011 & 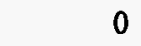 \\
\hline I3E-21354-0012 & 0 \\
\hline I3E-21354-0013 & 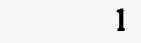 \\
\hline I3E-21354-0014 & 0 \\
\hline I3E-21354-0015 & 0 \\
\hline I3E-21354-0016 & 0 \\
\hline 13E-21354-0017 & 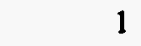 \\
\hline I3E-21354-0018 & 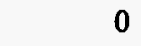 \\
\hline I3E-21354-0019 & 8 \\
\hline I3E-21354-0020 & A \\
\hline $13 \mathrm{E}-21354-0021$ & $A$ \\
\hline I3E-21354-0022 & \\
\hline I3E-21354-0023 & \\
\hline 13E-21354-0024 & \\
\hline 13E-21354-0025 & \\
\hline
\end{tabular}

Title

Loop Diagram - LLW Inlet Valve ROV-4936

Loop Diagram - LLW Inlet Valve ROV-4939

Loop Diagram - LLW Inlet Valve ROV -4940

Loop Diagram - Truck Unload Valve ROV-4955

Loop Diagram - Demineralized Water Pump (J-1712) Status

Loop Diagram - Control Room AHU1 Status

Loop Diagram - Fan EF4A Status

Loop Diagram - Fan EF5A Status

Loop Diagram - Fan EF6A Status

Loop Diagram - Truck Unloading Area AHU2 Status

Loop Diagram - Fan EF4B Status

Loop Diagram - Fan EF5B Status

Loop Diagram - Fan EF6B Status

Loop Diagram - Bottle Storage Area AHU3 Status

Loop Diagram - LAH-4933/4919 Sump Alarms

Loop Diagram - Tanker Truck Unload Permit

Loop Diagram - Bottle Room Door 15 Control \& Status

Loop Diagram - Bottle Rm. Airlock Door 14 Control \& Status

Loop Diagram - Control Door 12 Control \& Status

Loop Diagram - Truck Unloading Area Rollup Door 13 Control

Loop Diagram - Contrl Rm. Emergy Exit Dr. 11 Status

Loop Diagram - LAH4908A Tank Vault Sump Alarms

Loop Diagram - BEDA/PCU Interface

Piping \& Instrument Diagram Steam Distribution System

Piping \& Instrument Diagram Caustic System

Piping \& Instrument Diagram Compressed Air Distribution System

Piping \& Instrument Diagram Process Waste System

Piping \& Instrument Diagram Low Level Waste System

Piping \& Instrument Diagram Potable/Process Water System

Piping \& Instrument Diagram HVAC System Building Area

Piping \& Instrument Diagram HVAC System Tank Area

Connection Diagram PW Control Valves ROV-4903, 4904, 4908, 4909, 4932 \& 4933

Connection Diagram PW Control Valves ROV-4919, 4926, 4929, 4931, 4935, 4938 \& 4941

Connection Diagram LLW Control Valves ROV-4911, 4917, 4934 \& 4954

Connection Diagram LLW Control Valves ROV-4918, 4920, 4925,

$4936,4939,4940$ \& 4955

Instrument Location - Plan at Grade

Instrument Location - Roof Plan

Instrument Location - Plan Below Grade

Instrument Location Chart

Instrument Air Plan at Grade

Instrument Air Roof Plan

Instrument Air Plan Below Grade

Assembly Panel K4902 Side "A", "B", "C"

Panel K4902 - Cutout and Drilling Details

Assembly Panel K4902 - Side E \& F

Assembly Panel K4903 - Side "A", "B", \& "C"

Panel K4903 - Cutout and Drilling Details

Panel K4903 - Process Waste Graphic Display 
TRANSPORTED WASTE RECEIVING FACILITY - BUILDING 2649 (continued)

$\begin{array}{lr}\begin{array}{l}\text { Drawing } \\ \text { Number }\end{array} & \text { Revision } \\ \text { I3E-21354-0026 } & \text { A } \\ \text { I3E-21354-0027 } & \text { A } \\ \text { I3E-21354-0028 } & \text { A } \\ \text { I3E-21354-0029 } & \text { A } \\ \text { I3E-21354-0030 } & \text { A } \\ \text { I3E-21354-0031 } & \text { A } \\ \text { I3E-21354-0032 } & \text { A } \\ \text { I3E-21354-0033 } & \text { A } \\ \text { I3E-21354-0034 } & \text { A } \\ \text { I3E-21354-0035 } & \text { A } \\ \text { I3E-21354-0036 } & \text { A } \\ \text { I3E-21354-0037 } & \text { A } \\ \text { I3E-21354-0038 } & \text { A } \\ \text { I3E-21354-0039 } & \text { A } \\ \text { I3E-21354-0040 } & \text { A } \\ \text { I3E-21354-0041 } & \text { A } \\ \text { I3E-21354-0042 } & \text { A } \\ \text { I3E-21354-0043 } & \text { A } \\ \text { I3E-21354-0044 } & \text { A } \\ \text { I3E-21354-0045 } & \text { A } \\ \text { I3E-21354-0046 } & \text { A } \\ \text { I3E-21354-0047 } & \text { A } \\ \text { I3E-21354-0048 } & \text { A } \\ \text { I3E-21354-0049 } & \text { A }\end{array}$

I3E-21354-0050

I3E-21354-0051

I3E-21354-0052

I3E-21354-0053

I3E-21354-0054

I3E-21354-0055

I3E-21354-0056

I3E-21354-0057

I3E-21354-0058

I3E-21354-0059

I3E-21354-0060

I3E-21354-0061

I3E-21354-0062

I3E-21354-0063

I3E-21354-0064

I3E-21354-0065

I3E-21354-0066

I3E-21354-0067

I3E-21354-0068

13E-21354-0069

I3E-21354-0070

I3E-21354-0075

I3E-21354-0076
A

0

0

1

0

0

A

A

A

B

B

A

B

A

B

B

A

A

A

A

0

A

0

0

\author{
Title \\ Assembly Panel K4903 - Side "D" \& "F" \\ Assembly Panel K4904 - Side "A", "B", \& "C" \\ Panel K4904 - Cutout and Drilling Details \\ Panel K4904 - Low Level Waste Graphic Display \\ Assembly Panel K4904 - Side "D" \& "F" \\ Assembly Panel K4905 - Side "A", "B" \& "C" \\ Panel K4905 - Cutout and Drilling Details \\ Assembly Panel K4905 - Side "E" \& "F" \\ Assembly Panel K4906 - Side "A", "B", \& "C" \\ Panel K4906 - Cutout and Drilling Details \\ Assembly Panel K4906 - Side "E" \& "F" \\ Assembly Panel K4907 \\ Assembly Panel K4908 \\ Assembly Panel K4909 \\ Assembly Panel K4910 \\ Assembly Panel K4911 \\ Assembly Panel K4912, 4913, 4914 \& 4915 \\ Assembly Panel K4916 and K4920 \\ Assembly Panel K4917 \\ Assembly Panel K4918 and K4919 \\ Assembly Panel K4921 and K4922 \\ Assembly Panel K4923 \\ Assembly Panel K4924 \\ Instrument Installation \\ Instrumentation \\ Instrument Installation \\ Instrument Installation \\ Instrument Installation \\ Instrument Installation \\ Instrument Installation \\ Panel K4902 - Wiring Diagram Side "D" \\ Panel K4902 - Wiring Diagram Side "E" \\ Panel K4902 - Wiring Diagram Side "F" \\ Panel K4903 - Wiring Diagram Side "D" \& "F" \\ Panel K4904 - Wiring Diagram Side "D" \& "F" \\ Panel K4905 - Wiring Diagram Side "D" \& "F" \\ Panel K4905 - Wiring Diagram Side "E" \\ Panel K4906 - Wiring Diagram Side "D" \& "F" \\ Panel K4906 - Wiring Diagram Side "E" \\ Panel K4907 - Wiring Diagram \\ Panel K4908 - Wiring Diagram \\ Panel K4909 - Wiring Diagram \\ Panel K4910 - Wiring Diagram \\ Panel K4911 - Wiring Diagram \\ Instrument Installation \\ Installation Details, Panel K4925 \\ Instrument Installation \\ Instrument Installation
}




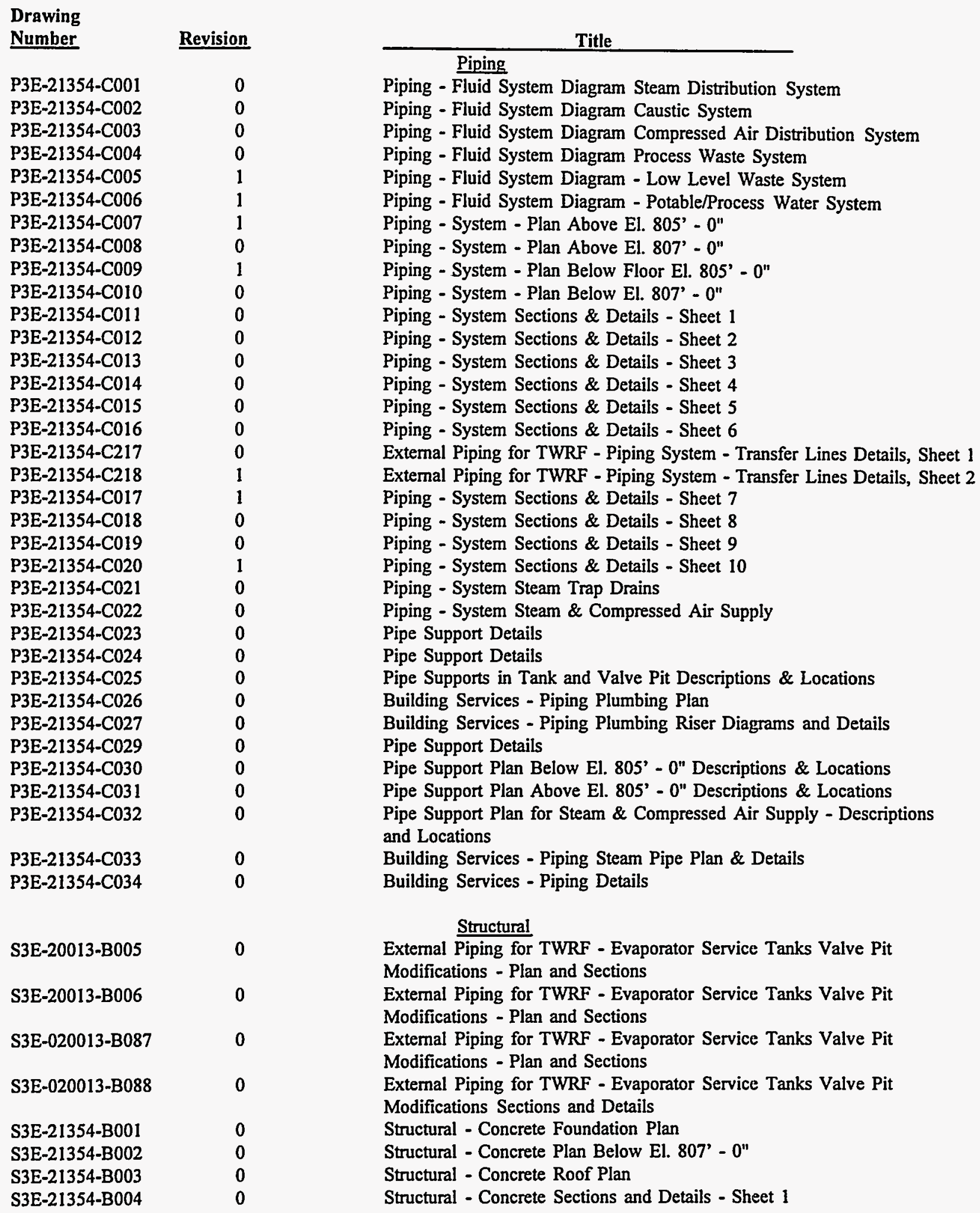


TRANSPORTED WASTE RECEIVING FACILITY - BUILDING 2649 (continued)

Drawing

Number

S3E-21354-B005

S3E-21354-B006

S3E-21354-B007

S3E-21354-B008

S3E-21354-B009

S3E-21354-B010

S3E-21354-B028

S3E-21354-B029

S3E-21354-B030

S3E-21354-B031

S3E-21354-B032

S3E-21354-B033

S3E-21354-B034

S3E-21354-B035

S3E-21354-B036 $\underline{\text { Revision }}$

0

0

0

0

0

0

0

0

0

0

0

0

0

0
Title

Structural

Structural - Concrete Sections and Details - Sheet 2

Structural - Concrete Sections and Details - Sheet 3

Structural - Steel Liner Plate Embedments \& Details

Structural - Concrete Sections \& Details - Sheet 4

Structural - Concrete Sections \& Details - Sheet 5

Structural - Concrete Sections \& Details - Sheet 6

Structural - Steel HVAC Equip. Support Details - Sheet 1

Structural - Steel HVAC Equip. Support Details - Sheet 2.

Structural - Steel HVAC Equip. Support Details - Sheet 3

Structural - Steel HVAC Duct Support Details - Sheet 1

Structural - Steel HVAC Duct Support Details - Sheet 2

Structural - Concrete Sec. \& Details - Sheet 7

Structural - Concrete Sec. \& Details - Sheet 8

Structural - Concrete Sec. \& Details - Sheet 9

Structrual - Steel HVAC Access Platforms 
DOE/OR/01-1312\&D2

ORNL/ER-273\&D2

\section{DISTRIBUTION}

1. A. D. Clay

2. R. A. Dean

3-4. J. T. Etheridge

5-6. T. H. Monk

7. C. E. Mulkey

8. P. S. Wood

9. Central Research Library

10. Central ER Doc. Mgmt. Center

11. ORNL Doc. Mgmt. Center-RC

12. Laboratory Records Department

13. ORNL Patent Section

14. WMRA Document Management Center

15. Office of Assistant Manger for Energy Research and Development, DOE Oak Ridge Operations Office, P.O. Box 2001, Oak Ridge, TN 37831-8600

16. R. O. Hultgren, DOE Oak Ridge Operations Office, P.O. Box 2001, Oak Ridge, TN 37831-8541

17. C. S. Mims, DOE Oak Ridge Operations Office, P.O. Box 2001, Oak Ridge, TN 37831-8541

18. L. L. Radcliffe, DOE Oak Ridge Operations Office, P.O. Box 2001, Oak Ridge, TN 37831-8541

19. L. C. M. Roddye, DOE Oak Ridge Operations Office, P.O. Box 2001, Oak Ridge, TN 37831-8541

20-21. Office of Scientific and Technical Information, P.O. Box 62, Oak Ridge, TN 37831 